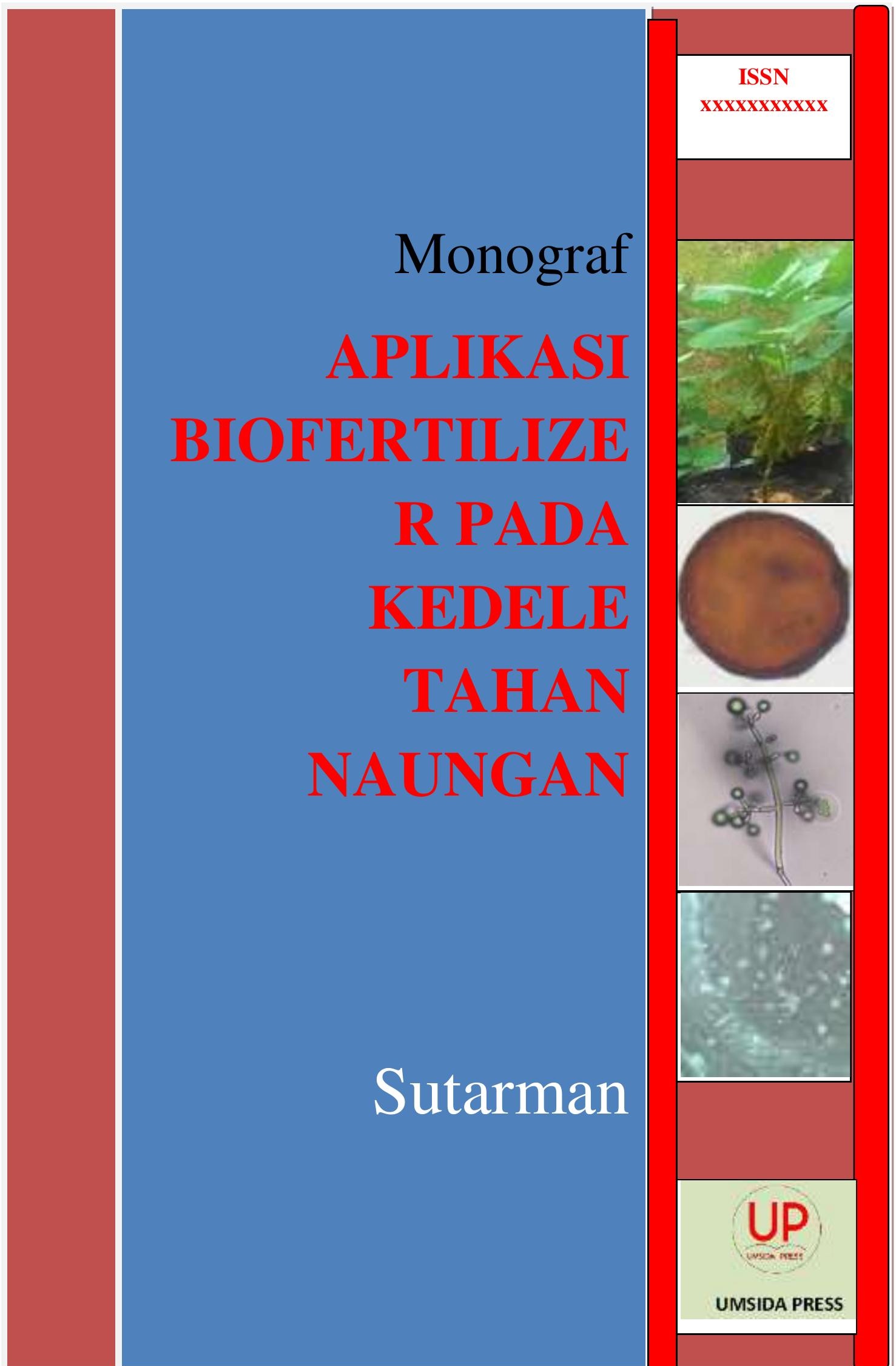




\title{
Monograf
}

\section{APLIKASI BIOFERTILIZER PADA KEDELE TAHAN NAUNGAN}

\author{
Oleh \\ Sutarman
}

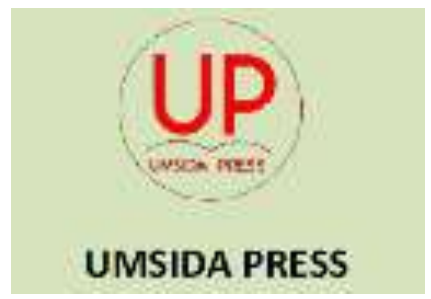

Diterbitkan oleh UMSIDA PRESS

Jl. Mojopahit 666 B Sidoarjo

ISBN: 978-979-3401-92-8

Copyright@2018

Sutarman

All rights reserved

Hak cipta dilindungi undang-undang.

Dilarang memperbanyak atau memindahkan sebagian atau seluruh isi buku ini ke dalam bentuk apapun, secara elektronis, maupun mekanis, termasuk fotokopi, merekam, atau dengan teknik perekaman lainnya, tanpa izin tertulis dari penerbit.

[Berdasarkan UU No. 19 Tahun 2000 tentang Hak Cipta Bab XII Ketentuan Pidana, Pasal 27, Ayat (1), (2), dan (6). 
Monograf

APLIKASI BIOFERTILIZER

PADA KEDELE

TAHAN NAUNGAN

Penyusun

Sutarman

Dosen Program Studi Agroteknologi

Fakultas Pertanian, Universitas Muhammadiyah Sidoarjo

Editor ahli

Prof. Dr. Ir. Dyah Roeswitawati, MS

Editor

Dyah Satiti

Penerbit

UMSIDA PRESS

P3I Universitas Muhammadiyah Sidoarjo

Kampus 1 Universitas Muhamamdiyah Sidoarjo

Jl. Mojopahit 666 B Sidoarjo, Jawa Timur, Indonesia

Telp. +62 318945444

Fax +62 318949333

https://p3i.umsida.ac.id 


\section{KATA PENGANTAR}

Puji syukur kehadirat Allah SWT atas tersusunnya monograf dengan judul: "Aplikasi Biofertilizer pada Kedele Tahan Naungan" yang merupakan salah satu luaran penelitian sesuai kompetensi penyusun di bidang kesehatan dan penyakit tanaman serta mikrobiologi tanah pertanian.

Buku ini disusun berdasarkan hasil penelitian dan kajian literatur yang bersumber pada berbagai artikel jurnal Internasional relevan terkait.

Nilai kebaruan penelitian ini adalah pemanfaatan isolat nodul akar tumbuhan liar putri malu (Mimosa pudica) yang diintegrasikan dengan biofertilizer endomikoriza dan Trichoderma dari lantai hutan pada tanaman kedele tahan naungan. Hasil penelitian ini diharapkan dapat menjawab tantangan pewujudan swasembada kedele dengan mengoptimalkan lahan hutan tanaman, perkebunan, dan sistem tumpangsari lahan kering lainnya yang belum pernah ditanami kedele sebelumnya dengan kondisi intensitas sinar matahari yang relatif sedang hingga rendah.

Pada kesempatan ini penulis menyampaikan terima kasih kepada: Rektor Universitas Muhammadiyah Sidoarjo (UMSIDA), Dekan, Ketua Program Studi Agroteknologi serta Kepala Laboratorium Agrokompleks Fakultas Pertanian UMSIDA atas dukungan moril dan fasilitas yang disediakan bagi kelancaran penelitian dan penyusunan buku ini.

Semoga karya ilmiah ini bermanfaat.

Sidoarjo, Maret 2018

Penyusun 


\section{DAFTAR ISI}

Halaman

I. PENDAHULUAN …………………………........ 1

II. AGENSIA BIOFERTILIZER …………………….... 5

2.1 Biofertilisasi Bahan Organik ................................... 5

2.2 Trichoderma …………………………………….... 7

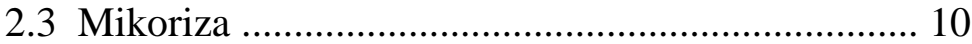

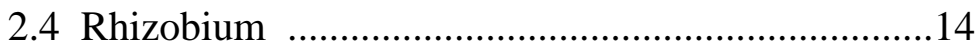

III. TEKNOLOGI BIOFERTILIZER ............................. 16

IV. METODE PENELITIAN ………………………......... 19

4.1 Produksi Biofertilizer ............................................. 19

4.1.1 Isolasi dan pengujian bakteri nodul akar .... 19

4.1.2 Formulasi biofertilizer Trichoderma ........... 20

4.1.3 Isolasi dan formulasi biofertilizer Mikoriza 22

4.2 Aplkasi Biofertilizer ............................................... 23

4.3 Variabel Pengamatan ………………………..... 25

4.3.1 Uji keragaan bakteri nodul akar ............... 25

4.3.2 Uji aplikasi biofertilizer .......................... 25

4.4 Rancangan Perobaaan dan Analisis Statistika .... 26

4.4.1 Pengujian keragaan bakteri nodul akar ....... 26

4.4.2 Aplikasi biofertilizer .................................. 27

V. HASIL DAN PEMBAHASAN ............................... 28

5.1 Keragaan Agen Biofertilizer ................................ 28

5.1.1 Pengujian isolat bakteri nodul akar ............ 29

5.1.2 Formulasi biofertilizer Trichoderma ......... 29

5.1.3 Isolasi dan formulasi biofertilizer Mikoriza 30

5.2 Uji Aplikasi Biofertilizer ………………….... 31

5.2.1 Pertumbuhan vegetatif .............................. 31

5.2.2 Nodul akar dan intensitas infeksi mkoriza 34

5.2.3 Produksi tanaman ................................. 36

5.3 Pembahasan Umum .......................................... 37 
VI. KESIMPULAN DAN SARAN 43

5.1 Kesimpulan ........................................................ 43

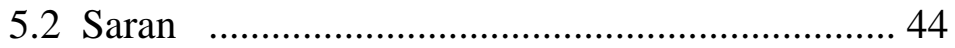

DAFTAR PUSTAKA …...................................... 45

LAMPIRAN ........................................................ 56 


\section{BIODATA PENULIS}

Dr. Ir. Sutarman, MP lahir di Lampung, 5 Januari 1963. Pendidikan S1 pada Program Studi Hama dan Penyakit Tanaman Universitas Lampung 1984-1988, S2 pada Program Studi Ilmu Tanaman KPK PPS UGM-UNIBRAW 1992-1994, dan Program Doktor Ilmu Kehutanan Institut Pertanian

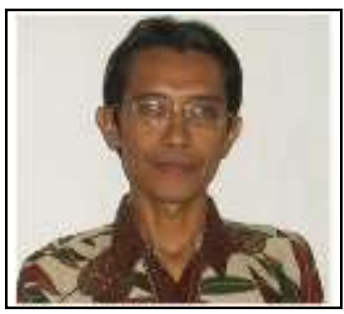

Bogor (IPB) 1998-2003. Pada program studi Agroteknologi Faultas Pertanian Universitas Muhammadiyah Sidoarjo (UMSIDA), penulis diberi kepercayaan untuk mengampu mata kuliah Pengelolaan Hama Penyakit Terpadu, Kesuburan dan Mikrobiologi Tanah, Teknologi Bioremediasi, Dasar-dasar Perlindungan Tanaman, dan Kultur Jaringan. Dalam aktivitas penelitiannya penulis mendapat berbagai bentuk hibah penelitian dari Kemenristekdikti seperti: Penelitian Fundamental (20142015), Penelitian Unggulan PT (2016), Penelitian Terapan (2016 sebagai anggota), Penelitian Hibah Kompetensi (2017), Penelitian Dasar Unggulan PT (2018-2020 sebagai anggota), dan Penelitian Terapan Unggulan PT (2018-2020). Berbagai luaran di antaranya dalam bentuk artikel jurnal, publikasi seminar/prosiding, buku ajar, dan Teknologi Tepat Guna. Saat ini penulis menjabat sebagai ketua Program Studi Agroteknologi di UMSIDA sekaligus pembina dan perancang Klinik Agrokompleks Faperta UMSIDA yang kegiatannya melayani konsultasi dan pendampingan kelompok tani di Sidoarjo, Mojokerto, Pasuruan, dan wilayah lain di Jawa Timur. Penulis juga aktif sebagai Sekretaris Asosiasi Program Studi Agroteknlogi Muhammadiyah periode 2017-2021. 


\section{BAB I PENDAHULUAN}

Kedele merupakan komoditas yang paling sulit untuk diwujudkan status keswasembadaannya jika dibandingkan dengan beras dan jagung. Produksi kedele Indonesia sampai tahun 2015 hanya 998.000 ton, sementara itu secara nasional kebutuhan kedele mencapai 2,54 juta ton (BPS, 2016). Di lain pihak luas panen kedele makin menurun dari waktu ke waktu. Pada tahun 1997 luas panen kedele mencapai 1.118.140 Ha, tetapi pada tahun 2015 menurun drastis menjadi 614.095 Ha. Penurunan juga terjadi pada semua wilayah sentra produksi kedele termasuk provinsi Jawa Timur yang mengalami penurunan luas panen dari 414.748 Ha (2015) menjadi 208.067 Ha (2010) (BPS. 2016).

Upaya menciptakan kemandirian pangan khususnya komoditas kedele tidak cukup dengan mengembangkan potensi intrinsik varietas-varietas kedelai yang ada serta teknologi pemupukan dan rekayasa kesuburan tanah, tetapi juga pengembangan luas area tanam. Pemanfaatan lahan kering merupakan alternatif paling strategis bagi swasembada kedele. Di Indonesia tersedia 144,47 juta hektar lahan kering yang tersebar di Kalimantan 4,61\%, Sumatera 33,25\%, Papua 28,6\%, Sulawesi 16,57\% , Jawa 10,7\%, dan Maluku 7,45 (Yulida, 2016). Di lain pihak tersedia lahan yang belum 
termanfaatkan yaitu tegal atau kebun yang kurang produktif 12,01 juta hektare dan lahan tidur 11, 7 juta hektare. Namun untuk memanfaatkan lahan kering dimaksud akan ditemui berbagai kendala yang berat di antranya adalah: (i) degradasi kesuburan tanahnya dan rendahnya kandungan $\mathrm{C}$ organik tanah (<2\%) (Suriadikarta dan Simanungkalit, 2006); (ii) ancaman cekaman kekeringan saat terutama musim kemarau (Anonim. 2017); (iii) $\mathrm{pH}$ rendah (kemasaman tanah), kapasitas tukar kation rendah, dan kahat P (Atman, 2006); dan (iv) potensi gangguan penyakit tanaman (Sarjan dan Sab'i, 2014).

Sebagai bagian dari lahan kering yang secara teknis mendapat perlakuan agronomis, area perkebunan, hutan tanaman, tegalan, dan bentuk lahan kering lainnya yang sebagian besar periode siangnya tertutupi oleh tajuk tanaman, juga memiliki potensi untuk dimanfaatkan bagi pengembangan pertanaman kedele. Salah satu bentuk aplikasinya adalah sebagai tumpang sari dalam sistem agroforestri.

Ada kelemahan dalam sistem tumpangsari yaitu akan dihasilkannya kondisi tumpang-tindih tajuk. Pada tumpangsari jagung dan kedele misalnya, dihasilkan naungan dengan intensitas sekitar 30\% - 50\% bagi tanaman kedele (Polthanee dan Treloges, 2002). Terjadinya naungan 
terhadap tanaman kedele juga akan dihasilkan pada tanaman perkebunan dan hutan tanaman.

Khusus pada lahan yang sering dinaungi tajuk ini, kendalanya adalah respons tanaman yang rendah terhadap naungan. Penelitian yang sudah dilakukan adalah pengembangan varietas kedele lokal yang tahan naungan hingga 50\% (Balibang Pertanian, 2016) dan 50-70\% (Komariah, Waloeyo, dan Hidayat, 2017). Salah satu varietas yang memiliki spektrum penaungan yang luas adalah varietas Dena-1 yang memiliki kemampuan menjaga produksi optimal hingga naungan 50\%. Di lain pihak naungan yang terbentuk dalam sistem agroforestri bisa mencapai tingkat melebihi 50\%. Untuk itu perlu pengujian ketahananan varietas ini terhadap naungan hingga $60 \%$ suatu kondisi yang dijumpai pada lingkungan hutan/perkebunan sengon, pinus, dan berbagai tanaman hutan dan perkebunan terutama pada tanaman keras tingkat pancang.

Karakteristik lahan kering yang terlantar dan/atau belum termanfaatkan relatif tidak sama dengan lahan yang biasa digunakan untuk budidaya. Hal yang menguntungkan adalah bahwa lahan tersebut relatif belum tercemar bahan kimia buatan (pestisida dan pupuk kimia). Di samping itu tanah pada lahan dimaksud selalu dijumpai tumbuhan liar dan berbagai jenis mikroba yang berpotensi sebagai simbion bagi 
tumbuhan polong-polongan termasuk kedele. Salah satu tumbuhan liar dan masuk dalam keluarga polong-polongan pada lahan yang belum dimanfaatkan untuk penenaman kedele adalah putri malu (Mimosa pudica) yang pada akarnya dijumpai nodul akar. Belum banyak diketahui sejauhmana kesesuaian bakteri nodul akar yang berasal dari akar tumbuhan putri malu dengan tumbuhan kedele yang akan dibudidayakan.

Di lain pihak pemanfaaatan fungi efektif bagi peningkatan kesuburan tanah dan dengan tujuan meningkatkan kesehatan dan ketahanan tanaman terhadap cekaman patgoen dan cekaman lingkungan mulai banyak dikembangkan. Saat ini pemanfaatan Trichoderma sebagai agensia hayati pengendali penyakit dan sebagai agensia biofertilizer sudah mulai berkembang. Namun demikian bagaimana fungi ini dapat bersinergi dengan bakteri Rhizobium dan fungi mikoriza pada tanaman kedele di rhizosfer khusus lahan kering perlu diuji.

Trichoderma dan fungi endomikoriza memiliki habitus dan niche yang hampir sama. Propagul Trichoderma dan hifat eksternal fungi mikoriza berada di rhizosfer. Untuk itu perlu diuji sejauhmana interaksi dan perilaku saling mempengaruhi di anatra keduanya dan dalam rhizosfer serta efeknya terhadap pertumbuhan tanaman. 
Penelitian ini bertujuan:

(i) Untuk mengetahui kemampuan bakteri nodul akar dari tumbuhan putri malu (M. pudica) sebagai simbion efektif pada tanaman kedele;

(ii) Untuk mengetahui pengaruh naungan $60 \%$ terhadap pertumbuhan vegetatif dan produksi tanaman kedele pada media yang diberi biofertilizer Trichoderma dan diinokulasi isolat bakteri nodul akar dari akar tumbuhan putr malu;

(iii) Untuk mengetahai pengaruh biofertilizer endomkoirza Glomus sp. berpengaruh terhadap pertumbuhan vegetatif dan produksi tanaman kedele pada media yang diberi biofertilizer Trichoderma dan diinokulasi isolat bakteri nodul akar dari akar tumbuhan putri malu;

(iv) Untuk mengetahu pengaruh interaksi antara naungan 60\% dengan aplikasi biofertilizer endomikoriza terhadap pertumbuhan vegetatif dan produksi tanaman kedele pada media yang diberi biofertilizer Trichoderma dan diinokulasi isolat bakteri nodul akar dari akar tumbuhan putri malu. 


\section{BAB II \\ AGENSIA BIOFERTILIZER}

\subsection{Biofertilisasi}

Di alam telah terjadi proses dekomposisi bahan organik sekaligus bersifat pemupukan atau penambahan/pemulihan nutrisi ke dalam tanah yang difasilitasi oleh aktivitas mikroba yang dibuktikan adanya proses respirasi. Heinemeyer et al. (2007) menunjukkan aktivitas respirasi dalam bentuk dalam aliran CO2 tanah yang ditanggung-jawabi oleh organisme heterotrof tanah (60\%) dan hifa ektomikoriza (25\%), dan akar $15 \%$. Fakta lain menunjukkan bahwa repirasi 25\% respirasi akar barley ditanggung-jawabi oleh respirasi hifa mikoriza arbuskula yang berkontribusi sebesar $4,8 \%$ total asimilasi karbon (Moyano et al., 2007).

Fungi mikoriza ericoid sebagaimana tipe mikoriza yang lain berperan dalam pendegradasian bahan organik. menyebutkan karena menghasilkan berbagai enzim yang dapat digunakan untuk mendegradasi dinding sel tanaman yang merupakan bahan organik (Read dan Perez-Moreno, 2003).

Karakeristik tanah ternyata sangat mempengaruhi kualitas simbiosis yang direpresntasikan oleh pertumbuhan panjang akar dan kelimpahan fungi mikoriza arbuskula 
(FMA) (Camenzind et al., 2016). Di lain pihak status $\mathrm{N}$ tanah terkait dengan biofertilisasi berbasis endomikoriza sangat dapat dipengaruhi kualitas lapisan organik di samping suhu dan kelembaban tanah yang merupakan representasi ketinggian tempat (Martinson et al., 2013).

Aktivitas metabolisme dekomposer dalam proses dekomposisi bahan organik di dalam tanah dan akan akan menyumbangkan suatu dinamika perubahan laju respirasi dan aktivitas mikroba tanah yang berkontribusi terhadap turn over bahan organik tanah (Kuzyakov dan Larionova, 2005) yang dikukur oleh tingkat respirasi rhizosfer. Terkait itu maka, ketersediaan bahan organik di dalam tanah menjadi sangat penting untuk konservasi mikroflora tanah, mengngat pula bahwa bebeapa jneis mikroba memiliki tingkat respirasi yang lebih besar dari pada akr tanaman seperti dicontohkan oleh Neumann dan Matzner (2014) bahwa tingkat respirasi akar halus lebih rendah dari miselium fungi ektomikoriza. Respirasi karbon miselia fungi mikoriza arbuskula pada hutan tropis basah mencapai 1,4 ton/ha per tahun atau ratarata $14 \pm 6 \%$ respirasi tanah dan $26 \pm 12 \%$ respirasi akar (Nottingham et al., 2010). 
Biofertilisasi oleh mikroorganisme merupakan representasi hubungan antara turn over $\mathrm{C}-\mathrm{N}$ tanah dan aktivitas enzim ekstraseluler seperti selulase (exocellulase dan $\beta$-glukosidase) dan protease (Geisseler dan Horwath (2009).

Biofertilisasi bahan organik oleh fungi mikoriza ditandai adanya glomalin yaitu senyawa glikoprotein yang diproduksi hifa Fungi mikoriza arbuskula; senyawa ini $\mathrm{C}$ dan $\mathrm{N}$ dalam glomalin ternyata mencapai antara $4-5 \% \mathrm{C}$ dan $\mathrm{N}$ tanah (Rillig et al., 2001).

Mikroorganisme bukan hanya penyumbang nutrisi di dalam tanah, tapi juga berperan dalam siklus makroagregat tanah dan pembentukan mikroagregat tanah seperti diilustrasikan pada Gambar 1 (Six et al., 2004). Model konseptualnya dapt dijelaskan bahwa: bahan organik tanah dalam angka panjang dilindungi oleh mikroaggregat tanah dan stabilisasi bahan organik tanah ditanggung-jawabi oleh makroaggregate tanah. 


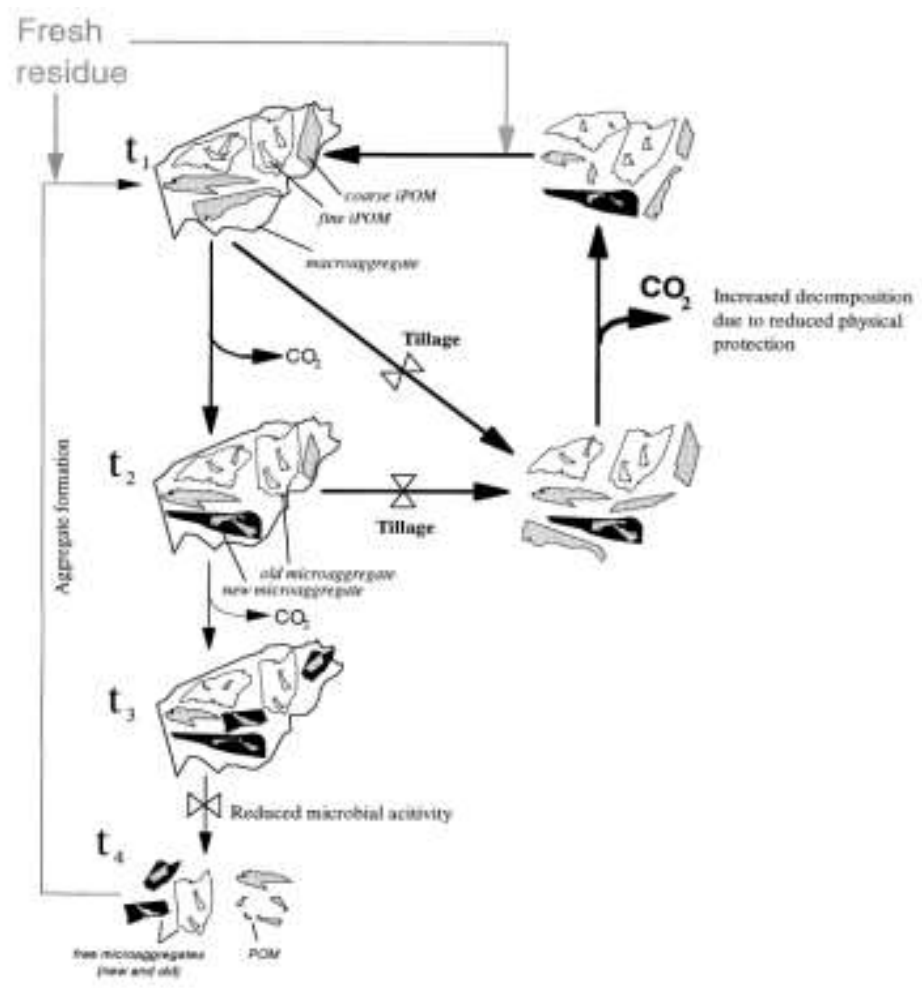

Gambar 2.1 Model konseptual yang menunjukkan cycle life macroaggregate dan pembentukan microaggregates. IPOM = partikulat bahan organik intraaggregate;. $\mathrm{POM}=$ partikulat bahan organik;. T waktu; $\nabla-$ Tingkat proses modifikasi) (Six et al., 2000)

\subsection{Trichoderma}

Fungi genus Trichoderma ada di mana-mana di seluruh dunia serta mudah diisolasi dari tanah, kayu yang melapuk, dan berbagai bentuk bahan organik lainnya (Howell, 2003). Sejauh ini terdapat tidak kurang dari 89 spesies Trichoderma yang teridentifikasi dan banyak spesies Hypocrea sebagai 
anamorf Trichoderma; keduanya congeneric (Samuels, 2006).

Dari 30 lokasi hutan pinus di Jawa Timur diperoleh 30 isolat Trichoderma unggulan dari masing-masing lokasi, dan mengacu pada kunci determinasi spesies Trichoderma (Gamas dan Bissett, 2002) diketahi bahwa salah di antaranya adalah Trichoderma harzianum yang berpotensi sebagai biopestisida sekaligus biofertilizer (Sutarman, 2016a).

Keunggulan Trichoderma di bandingkan dengan berbagai spesies fungi menguntungkan lainnya adalah beberapa karakter keragaan pentingnya yaitu: (i) menjadi parasit bagi fungi patogen (mikoparasit), (ii) menjadi kompetitor kuat bagi mikroba tanah lainnya, dan (iii) menghasilkan senyawa pengatur tumbuh bagi tanaman seperti siderophores serta karbon dan nitrogen permeases (Benítez et al., 2004; Verma et al., 2007; Hue et al. (2015), (iv) mendegradasi bahan organik menghasilkan nutrisi bagi tanaman (Buysens et al., 2016), dan (v) menghasilkan berbagai senyawa yang dapat menghambat patogen seperti enzim hidrolitik, antibiotik, enzim kitinase dan $\beta-1,3$ glucanases (Harman, 2006); bahkan menghasilkan senyawa anti dorman bagi bakteri (Pruksakorna et al. ; 2010).

Khusus mengenai kemampaunnya mengendalikan fungi patogen karena Trichoderma mensintesis berbagai senyawa 
protein yang merupakan antibiotik dan enzim hidrolitik yang dapat mendegradasi dinding sel meliputi selulase, kitinase, dan glukanase (Vinale et al., 2008; Al-Taweil et al., 2009). Bahkan T. harzianum selain menginduksi level kadar hormon optimal dan pertumbuhan tanaman (Gravel et al., 2007), juga dapat meningkatkan ketahanan terhadap patogen dengan cara menginduksi peningkatan aktivitas enzim peroksidase, polifenol oksidase dan superoksida dismutase pada tanaman tomat (Srivastava et al., 2010; Chowdappa et al., 2013) dan kentang (Youssef et al., 2016).

Status Trichoderma sebagai endofit yang terdeposit di ruang antarsel jaringan akar ternyata dapat meningkatkan ketahanan tanaman terhadap patogen akar (Yedidiaa et al., 2000) serta menekan Phytopthora palmivora penyebab hawar daun bibit kakao secara in vitro (Nurudin dan Sutarman, 2014) dan in vivo (Sutarman, 2016b). Trichoderma sp. Xy24 sebagai endofit pada daun, batang, dan kulit tanaman mangrove Xylocarpus granatum ternyata menghasilkan diterpenoid harziane yaitu (9R,10R)-dihydro-harzianone dan harzianelactone yang penting dalam ketahanan tanaman (Zhang et al., 2016).

\subsection{Mikoriza}

Secara umum para akhli mengklasifikasikan bentuk simbiosis antara fungi mikoriza ini dengan perakaran 
tanaman tiga kelompok yaitu: (i) ektomikoriza dengan ciri hifa fungi menginfeksi sel dan berada di ruang antar sel dan hifa eksternal menyelubungi bagian luar akar membentuk struktur seperti mantel sel akar, (ii) endomikoriza atau mikoriza arbuskula, hifa menginfeksi bagian dalam sel akar, dan hifa eksternalnya menjuntai ke luar akar namu tidak masif seperti ektomikoirza, (iii) ericoid mikoriza yang memiliki karakteistik khas berasosiasi dengan tanaman anggrek (Paul dan Clark, 1995).

Menurut Wang dan Qiu (2006) setidaknya 80\% spesies tanaman darat bersimbiosis dengan bermikoriza yang didominasi oleh jenis mikoriza arbuskular.

Fungi mikoriza arbuskula berperan penting dalam memperbaiki struktur tanah dan meningkatkan nutrisi tanaman pada padang rumput (van der Heijden et al., 2006).

Pada lahan kering Fungi mikoriza arbuskula mampu mendifusikan ion $\mathrm{NO}_{3}{ }^{-}, \mathrm{NH}_{4}+$, dan $\mathrm{PO}_{4}{ }^{3-}$ masing-masing sebesar $10^{-6}, 10^{-7}$, dan $10^{-8} \mathrm{~cm}^{2} \operatorname{det}^{-1}$ yang tidak mungkin dapat diperoleh oleh tanaman tanpa mikoriza (Paul \& Clark, 1995). Sementara itu Cavallazzi et al. (2007) menunjukkan efektivitas Glomus etunicatum dan S. pelusida dalam mempromosikan pertumbuhan tanaman melalui suplai hara secara signifikan berbagai unsur-unsur penting seperti $\mathrm{P}, \mathrm{Zn}$, $\mathrm{Cu}, \mathrm{Ca}, \mathrm{S}, \mathrm{Na}, \mathrm{N}, \mathrm{K}, \mathrm{Fe}$ dan $\mathrm{Al}$ ke dalam jaringan tanaman. 
(Tomè et al., 2015) menunjukkan adanya korelasi positif antara tingkat fotosintesis tanaman dan kapasitas penyerapan hifa, di mana 23\% $\mathrm{N}$-anorganik yang diserap dipertahankan di miselium fungi.

\subsection{Bakteri Nodul Akar}

Banyak spesies dan strain bakteri nodul akar pada berbagai tanaman polong-polongan, di antaranya adalah yang biasa bersimbiosis dengan akar kedele yaitu dari genus Rhizobium dan Bradyrhizobium (Paul dan Clark, 1996). Seperti halnya fungi Trichoderma dan endomikoriza, bakteri nodul akar berperan dalam meningkatkan kesuburan tanah, menghasilkan hormon tumbuhan (Altieri dan Nicholls, 2005). Bakteri nodul akar berperan penting dalam siklus $\mathrm{N}$ di alam yaitu dalam bentuk fiksasi nitrogen dari udara dan mengubahnya menjadi bentuk yang diperlukan bagi tanaman dan (Foyer dan Noctor, 2004). Simbiosis mutualistik di dalam tanah yang ditunjukkan oleh bakteri Rhizobium dengan tanaman kedelai (Glycine max L. Merr.) merupakan bagian dalam peranannya mendaur hara nitrogen (Sullivan, 2003).

Bakteri Rhizobium sesungguhnya adalah organisme heterotrof yang sumber energinya berasal dari oksidasi senyawa-senyawa organik seperti sukrose dan glucose yang dalam sistem simbiosis diperoleh dari tanaman inangnya (Foyer dan Noctor, 2004; Werner dan Newton, 2005; Dakora 
et al., 2008; Lichtfouse, 2010). Kelimpahan substrat yang dikeluarkan tanaman dalam bentuk berbagai metabolit, hormon, dan enzim-enzim perombak senyawa organik sangat diperlukan bagi berbagai mikroba tanah di daerah rizosfer (Singh et al., 2008). Di antara banyak ragam senyawa ekstraselular yang dihasilkan tanaman di rhozosfer, di antaranya merupakan senyawa yang bersifat sebagai sinyal atau inducer yang dikenal bakteri dan jenis-jenis senyawa tersebut akan menentukan kecocokan dengan bakteri pasangan simbion tanama (Werner dan Newton, 2005; Singh et al., 2008).

Nitrogen menjadi sdakah satu sentral bagi Berbagai kasus kekurangan $\mathrm{N}$ pada tanaman legum meskipun kandungan $\mathrm{N}$ dalam ruang udara tanah sangat tinggi yaitu dibandingkan gas yang lain yaitu sekitar $80 \%$ namun dalam kondisi tidak dapat dimanfaatkan langsung oleh tanaman (Dakora et al., 2008) kecuali melalui kinerja simbionnya yaitu bakteri nodul akar.

Mengingat ketergantungan kebutuhan $\mathrm{N}$ tanaman polong-polongan 50\% dari tanah (Paul dan Clark, 1996), maka sumbangan $\mathrm{N}$ lewat simbionnya sangatlah penting. Untuk itu penelitian pemanfaatan bakteri nodul akar sebagai biofertilizer telah lama dilakukan para ahli dan sudah terbukti manfaat aplikasi biofertilizer bakteri nodul akar dalam 
memperbaiki kesuburan tanah, meningkatkan pertumbuhan dan hasil tanaman, serta menekan pertumbuhan patogen (Altieri dan Nicholls, 2005; Purwaningsih, 2005), bahkan dapat meningkatkan produksi kedele sebesar 25-30\% di lahan masam Sumatera (Noortasiah, 2005). 


\section{BAB III TEKNOLOGI BIOFERTILIZER}

Pengembangan pemanfaatan mikroba sebagai bahan aktif biofertilizer tidak lepas dari riset dasar yang meliputi isolasi, uji keragaan secara in vitro, dan uji aplikasi memerlukan media buatan. Potato dextrose agar (PDA) yang dimodifikasi atau dengan penambahan rose bengal dan chloramphenicol atau streptomycin pada $\mathrm{pH} 6$ sering digunakan untuk menumbuhkan isolat-islat Trichoderma (Vargas Gil et al., 2009) dan disimpan disimpan dalam gliserol $0 \%$ pada suhu $-80^{\circ} \mathrm{C}$ (Saravanakumar et al., 2016).

Untuk fungi endomikoriza yang bersifat obligat tidak dapat ditumbuhkan pada media buatan, tetapi biasanya tumbuh pada perakaran inang tertentu misalnya tanaman jagung, yang pemeriksaan kelimpahan populasinya ditentukan melalui proses penyaringan bertingkat setidaknya dengan saringan $250-\mu \mathrm{m}$ dan kemudian saringan $50-\mu \mathrm{m}$ (García-González et al., 2016). Teknologi aplikasi mikoriza semakin berkembang sejalan berkembangnya metode pengujian efektivitas yang melibatkan pemanfaatan teknologi kultur in vitro di mana perkembangan infeksi fungi mikoriza arbuskula pada akar planlet dapat diamati langsung (Voets et al., 2015). 
Pemanfaatan Trichoderma saat ini bukan saja sebagai biofungisida terhadap patogen akar yang berarti menghemat penggunana bakan kimia fungisida tetapi juga sebagai biofertilizer yang dapat meningkatkan performa, kesehatan, dan produksi tanaman (Glare et al., 2012.)

Pemanfaatan Trichoderma sebagai agen biofertilizer dan agen biokontrol yang terformulasi dalam bahan organik (pupuk organik) menjadi prospek yang menjanjikan dalam strategi budidaya tanaman. Hal ini ditunjukkan oleh $\mathrm{Hu}$ et al. (2016) yang menerapkan strategi pengendalian Sclerotinia sclerotiorum dengan memanfaatkan Trichoderma sp. Tri-1 yang diformulasi dengan bungkil biji tanaman Kanola (Brasica juncea) dan jerami pada buddiaya tanaman kanola (oilseed rape). Integrasi kedua peran dalam satu jenis agensia hayati ini mampu menghilankan ancaman kehilangan hasil 10-80\% tanaman kanola sekaligus mengurangi secara signifikan penggunaan fungisida (Ma et al., 2009; Guan, 2011). Menurut Alguacil et al. (2014) penambahan jerami gandum dapat meningkatkan keanekaragaman fungi mikoriza arbuskula di samping meningkatakan aktivitas biologis tanah.

Trichoderma bisa diaplikasikan sebagai seed treatment untuk mengendalikan penyakit damping off. Dubey et al. (2007) menunjukkan kesuksesan aplikasi T. harzianum $\left(10^{6}\right.$ spora/ml/10 g biji) yang dikombinasikan dengan carboxin ( 2 
g per $1 \mathrm{~kg}$ biji) menurunkan kejadian penyakit damping off 42,6-72,9\% dan meningkatkan 12,0-14,0\% perkecambahan biji tanaman buncis. Sementara itu kombinasi $T$. viride dan Pseudomonas fluroescens yang diaplikasikan pada benih kapas untuk melindungi serangan patogen damping off Rhizoctonia solani dan Macrophomina phaseolina, ternyata mampu meningkatkan persentase perkecambahan benih serta meningkatkan pemanjangan akar dan tunas, bobot barangkasan, serta indeks vigor tanaman kapas (Shanmugaiah et al., 2009).

Aplikasi campuran fungi mikoriza arbuskula (Glomus mosseae, G. intraradices, G. clarum, Gigaspora gigantean, dan G. margarita) dalam bentuk suspensi spora pada berbagai tanaman mampu meningkatkan petumbuhan dan menginduksi ketahanan tanaman terhadap penyakit busuk akar Fusarium (Al Askar dan Rashad, 2010). 


\section{BAB IV \\ METODE PENELITIAN}

\subsection{Produksi Biofertilizer}

\subsubsection{Isolasi dan pengujian bakteri nodul akar}

Nodul akar tumbuhan putri malu (M. pudica) dilepas dari akar dan dicuci dengan air bersih, kemudian disterilkan secara permukaan dengan merendamnya dalam larutan alkohol $50 \%$ selama 30 detik, kemudian dibilas dalam air destilat steril sebanyak 3 kali. Setelah ditiriskan di atas kertas saring steril, sebanyak 1 gram nodul ditekan hingga hancur untuk kemudian ditempatkan di dalam air destilat volume 20 ml. Campuran diaduk rata dan diambil sebanyak $5 \mathrm{ml}$ untuk diencerkan dengan mmenambahkan air destilat hingga mencapai volume $100 \mathrm{ml}$. Cairan yang mengandung tanah tersebut diambil sebanyak $1 \mathrm{ml}$ dengan menggunakan siringe dan disemprotkan ke permukaan media PDA di cawan petri. Kegiatan tersebut dilakukan dalam kondisi aseptik di dalam laminar flow cabinet. Di lain pihak dengan cara yag sama diperlakukan pada nodul akar kedele varietas lokal Dena-1 (deskripsi pada Lampiran 1). Koloni yang muncul di permukaan media, dicuplik dan ditumbuhkan pada media yang baru, sehingga dihasikan sediaan isolat bagi keperluan pengujian. Setelah 5 hari, isolat bakteri nodul akar di cawan petri digunakan sebagai sumber inokulum dalam seeed 
treatment bagi pengujian kemampuan isolat tersebut bersimbiosis dengan akar tanaman kedele.

Sebanyak 50 gram kedele yang sudah disterilkan permukaannya dalam larutan alkohol 50\% selama 30 detik dicampurkan atau dilumuri isolat masing-masing dari nodul akar putri malau dan dari nodul akar kedele varietas Dena-1. Benih yang sudah terlumuri propagul isolat bakteri nodul akar tersebut ditanam dalam media tanam. Selanjutnya diamati bentuk dan ukuran nodulnya untuk melihat ada tidaknya kesesuaian inang yang ditunjukkan dengan respon pertumbuhan tanaman serta morfologi dan biomassa nodul yang terbentuk.

\subsubsection{Formulasi biofertilizer Trichoderma}

Fungi Trichoderma potensial yang dimanfaatkan sebagai pupuk hayati (biofertilizer) adalah isolat Tc-Jjr-02 (Gambar 2) yang merupakan salah satu dari 30 isolat Trichoderma isolat koleksi Laboratorium Mikrobiologi Fakultas Pertanian Universitas Muhammadiyah Sidoarjo. 


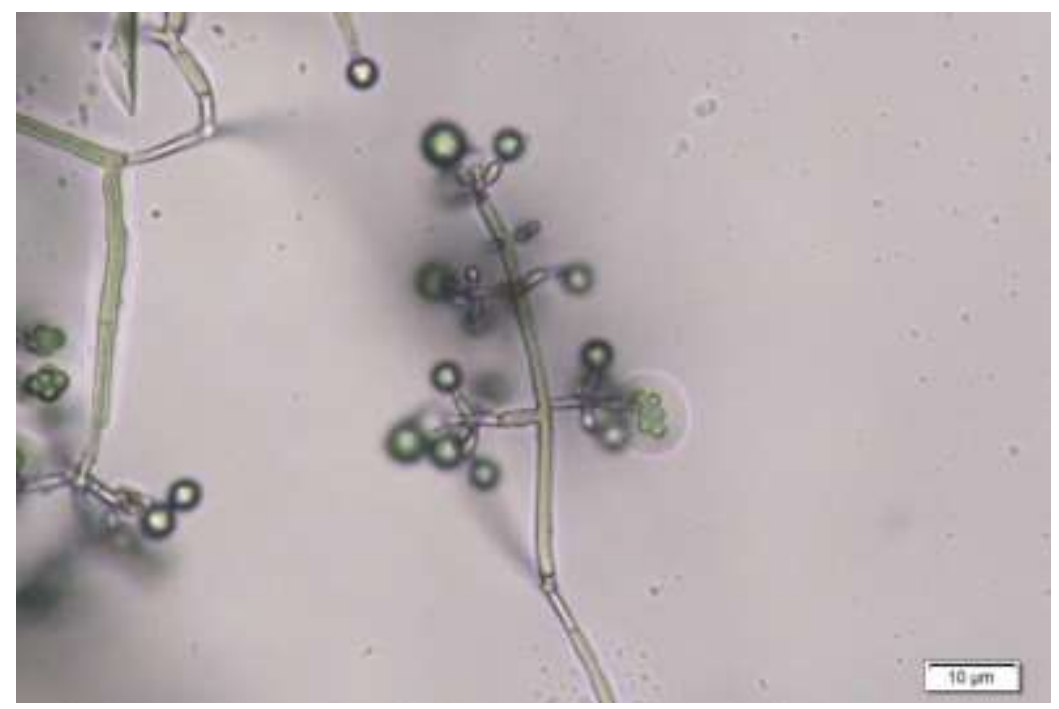

Gambar 2. Trichoderma harzianum islat Tc-Jjr-02 koleksi Laboratorium Mikrobiologi Fakultas Pertanian Universitas Muhamamdiyah Sidoarjo.

Tahap pertama dilakukan perbanyakan isolat dengan cara menempatkan cuplikan biakan berdiameter $5 \mathrm{~mm}$ pada media PDA-m (Vargas Gil, Pastorb, dan Marcha, 2009), kemudian diinkubasi selama 1 minggu. Biakan yang diperoleh diformulasi dalam kompos steril yang komposisi nutrisinya tertera pada Lampiran 1. Tiap satu cawan biakan dapat dicampur dengan $5 \mathrm{~kg}$ kompos. Selanjutnya campuran tersebut diinkubasi selama dua minggu sehingga dapat berstatus sebagai biofertilizer yang akan digunakan untuk tahap percobaan selanjutnya. Pada akhir periode inkubasi tersebut dihitung populasi isolat per gramnya. 


\subsubsection{Isolasi dan formulasi biofertilizer mikoriza}

Isolasi terhadap endomikoriza dilakukan terhadap tanah dari Pujon dengan pertimbangan bahwa di lokasi tersebut berpotensi dikembangkan tanaman kedele sebagai komoditas pertanian dalam sistem agroforestri. Namun demikian isolat endomikriza yang ditemukan nantinya perlu diuji-coba kemampuannya dalam pada daerah dengan ketinggian 300 $600 \mathrm{~m}$ dpl lahan kering yang belum termanfaatkan di mana biasa ditemukan tumbuhan putri malu (M. pudica).

Isolasi endomikoriza dilakukan dengan mengambil spora dari dalam tanah dengan modifikasi beberapa cara (GarciaGonzales et al., 2016), yaitu meliputi: (i) mencampur $2 \mathrm{~g}$ sampel tanah ke dalam air suling dan mengaduknya selama 30 detik, kemudian dituangkan dalam saringan bertingkat 250 $\mu \mathrm{m}$ dan $50 \mu \mathrm{m}$ dengan terus dialiri air, (ii) menuangkan partikel yang tertahan di saringan $50 \mu \mathrm{m}$ ke dalam gelas kimia dan diberi larutan sukrosa dan diaduk secara merata, (iii) suspensi dimasukkan ke dalam vial dan kemudian di sentrifugasi dengan kecepatan $1000 \mathrm{rpm}$ selama 5 menit, menuang cairan dan endapannya yang mengandung spora endomikoriza. Langkah selanjutnya adalah spora diamati di bawah mikroskop binokuler dengan perbesaran 100 kali dan mendeterminasi jenis endomikoriza. 
Untuk keperluan memperbanyak propagul mikoriza, maka dikecambahkan benih jagung pada baki perkecambahan yang medianya steril. Benih jagung yang berkecambah dan mulai muncul akar segera dipindahkan ke polibag kapasitas 5 $\mathrm{kg}$ yang tanahnya steril. Bersamaan dengan itu dituangkan cairan mengandung spora endomikoriza sebanyak sekitar 50 spora dalam $50 \mathrm{cc}$ air steril sehingga spora endomikoriza terdeposit di permukaan tanah sekitar akar kecambah jagung. Selanjutnya dilakukan pemeliharaan meliputi penyiraman dengan air steril dan pemberian pupuk dasar NPK (5 gr per polibag) hingga tanaman jagung berumur 6 minggu. Selanjutnya Tanaman jagung dibongkar dan semua tanah berikut akar tanaman diambil dan dihancur-ratakan. Campuran ini dapat digunakan sebagai biofertilizer mikoriza. Selanjutnya dilakukan pengamatan jumlah spora per gram formula.

\subsection{Aplkasi Biofertilizer}

Percobaan ini bertujuan untuk mengetahui respons tanaman kedele, yang akarnya bersimbiosis dengan bakteri nodul akar yang berasal dari akar putri malu, yang ditumbuhkan pada media tanaman yang mengandung Trichoderma isolat Tc-Jjr-02 (yang diformulasi sebagai kompos biofertilizer) terhadap: (i) aktivitas fungi mikoriza, (ii) naungan, dan (iii) aktivitas fungi mikloirza dan naungan. 
Dalam percobaan ini digunakan dua faktor yaitu: (i) aplikasi biofertilizer mikoriza, terdiri atas: tanpa mikoriza dan dengan mikoriza, dan (ii) naungan terdiri atas: tanpa naungan dan dengan naungan $60 \%$.

Bioferilizer fungi mikoriza yang sudah disiapkan dari kegiatan formulasi (4.1) digunakan untuk percobaan ini. Untuk naungan digunakan paranet yang mampu mengahalu intensitas sinar sebesar $60 \%$ atau sebanyak $40 \%$ dapat melewati paranet mencapai tanaman di bawahnya.

Benih kedele varietas Dena-1 disterilkan permukaannya dengan merendamnya beberapa saat ke dalam larutan alkohol $50 \%$ dan dibilasi dengan air destilat steril sebanyak tiga kali. Setelah ditiriskan, benih kedele dicampur dengan pupuk hayati bakteri nodul akar yang diformulasi dalam bentuk suspensi agar-agar cair hingga merata. Benih kedele yang sudah membawa propagul bakteri nodul akar ditempatkan di atas lubang tanam (kedalaman $2 \mathrm{~cm}$ dan diamatere $5 \mathrm{~cm}$ ) di dalam polibag yang sudah dialasi biofertilizer endomikoriza dengan total populasi rata-rata 50 spora dalam formulasi padatan curah yang terkonsentrasi di dasar lubang tanam. Untuk yang tidak menggunakan fungi endomikoriza, maka lubang tanam hanya dialasi kompos steril yang bahannya sama dengan kompos yang di dalamnya terformulasi spora endomikoriza. Adapun analisis kimia tanah yang digunakan 
sebagai media tanam dalam percobaan tertera pada Lampiran 2. Selanjutnya polibag baik yang diberi biofertilizer endomikoriza maupuan yang tidak diberi endomikoriza di tempatkan pada dua kondisi yaitu di bawah naungan paranet $60 \%$ dan tanpa naungan paranet.

Semua polibag berisi tanaman kedele percobaan dipelihara hingga tanaman panen dengan cara: penyiraman tiap hari pada sore hari pukul 17.00 yang diarahkan ke media tanam dalam polibag dengan air destilat hingga basah merata. Tiap tanaman dijaga bebas dari gangguan organisme hama dan penyakit tanpa mengandalkan bahan kimia pestisida.

\subsection{Variabel Pengamatan}

\subsubsection{Uji keragaan bakteri nodul akar}

Untuk pengujian keragaan bakteri nodul akar, variabel yang diukur adalah bobot total nodul akar pada umur 60 hari setelah tanam.

\subsubsection{Uji aplikasi biofertilizer}

Variabel yang diamati dalam percobaan uji aplikasi biofertilizer ini adalah sebagai berikut:

(i) Pertumbuhan vegetatif tanaman, yang diamati adalah panjang tanaman $(\mathrm{cm})$ mulai dari pangkal batang (sekitar $0,5 \mathrm{~cm}$ di atas permukaan tanah polibag) hingga ujung tajuk, jumlah daun yang 
sudah terbuka, dan diameter batang dengan cara mengukur garis tengah batang $(\mathrm{mm})$ pada ketinggian $2 \mathrm{~cm}$ di atas permukaan tanah polibag;

(ii) Produksi tanaman, yang diamati adalah jumlah polong per tanaman serta bobot total biji per tanaman (gr) dan bobot 100 butir biji yang ditimbang setelah dilakukan proses pengeringan biji;

(iii) Bobot nodul akar, yaitu dengan menimbang seluruh nodul akar segar per tanaman;

(iv) Intensitas infeksi mikoriza yang dilakukaan setelah pembongkaran tanaman saat panen.

\subsection{Rancangan Perobaaan dan Analisis Statistika}

\subsubsection{Pengujian keragaan bakteri nodul akar}

Dalam pengujian keragaan bakteri nodul akar ini, diperbandingkan kemampuan isolat bakteri nodul akar yang diperoleh dari akar tumbuhan putri malu ( $M$. pudica) dengan bakteri nodul akar yang diperoleh dari akar kedele varietas Dena-1. Perlakuan terdiri atas isolat nodul akar putri malu (R1) dan isolat nodul akar kedele (R2). Masing-masing isolat yang sudah diinokulasikan ke permukaan biji dan dipindahkan ke polibag setelah benih berkecambah. Masingmasing isolat ditumbuhkan pada delapan polibag. Data yang sudah teruji kenormalannya, dianalisis uji hipotesis t-test pada taraf uji 5\% dengan menggunakan Microsoft Excel 
dengan asumsi kedua sampel tersebut memiliki variance yang sama.

\subsubsection{Aplikasi biofertilizer}

Perlakukan dalam percobaan ini disusun menggunakan rancangan split-plot yang disusun dalam rancangan acak kelompok. Petak utama adalah naungan dalam bentuk paranet 60\% terdiri atas: tanpa naungan (N0) dan naungan 60\% (N1). Sebagai anak petak adalah pemberian biofertilizer mikoriza, terdiri atas: tanpa mikoriza (M0) dan dengan mikoriza (M1). Dari empat kombinasi perlakuan tersebut, percobaan diulang sebanyak 4 kali, sehingga diperoleh 16 satuan percobaan. Semua data dianalisis dengan Analisis Sidik Ragam pada taraj uji 5\% untuk mengetahui adanya perbedaan pengaruh perlakuan yang dapat dilihat signifikansinya pada F hitung. Pada variabel dengan F hitung yang menunjukkan siginifikansinya pada taraf uji 5\%, maka dilakukan uji beda nyata jujur (BNJ) pada taraf uji 5\% untuk mengetahui perbedaan antarperlakuan. 


\section{BAB V \\ HASIL DAN PEMBAHASAN}

\subsection{Keragaan Agen Biofertilizer}

\subsubsection{Pengujian isolat bakteri nodul akar}

Isolat yang diperoleh dari tumbuhan putri malu dan yang dari tanaman kedele secara fisik penampakan koloninya yang tumbuh dari suspensi hancuran nodul akar pada pengenceran $10^{5}$ (Gambar 1). Rerata total populasi bakteri nodul akar putri malu 2,56 x $107 \mathrm{cfu} / \mathrm{ml}$, sedangkan bakteri nodul akar kedele 3,4 x $107 \mathrm{cfu} / \mathrm{ml}$.
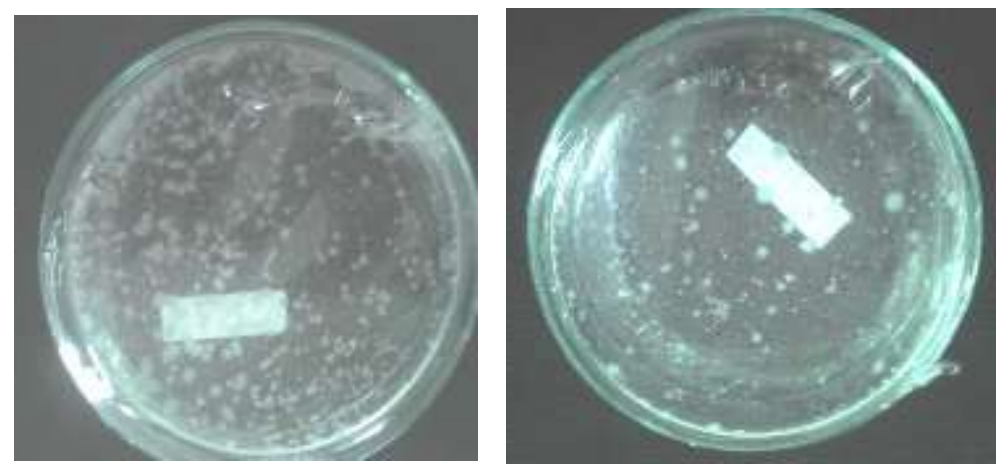

Gambar 3. Penampilan koloni bakteri nodul akar kedele (kiri) dan koloni bakteri akar putri malu (M. pudica)

Hasil uji hipotesis t-test (Tabel 1) dengan asumsi varians kedua sampel sama menunjukkan bahwa hipotesis diterima bahwa keragaan kedua isolat bakteri nodul akar tersebut sama. Seperti ditunjukkan pada Tabel 1 bahwa t hitung $>\mathrm{t}$ tabel dan $\mathrm{p}=0,209$, di mana rata-rata bobot nodul total per 
tanaman adalah 1,36 gr untuk putri malu dan 1,67 untuk kedele.

Tabel 1. Hasil uji t atas keragaan dua isolat bakteri nodul akar pada $60 \mathrm{HST}$

\begin{tabular}{lrr}
\hline & $\begin{array}{c}\text { Nodul akar } \\
\text { kedele }\end{array}$ & $\begin{array}{l}\text { Nodul akar } \\
\text { putri malu }\end{array}$ \\
\hline Mean & 1,671875 & 1,355 \\
Variance & 0,414356696 & 0,741828571 \\
Observations & 8 & 8 \\
Pooled Variance & 0,578092634 & \\
Hypothesized Mean Difference & 0 & \\
Df & 14 & \\
t Stat & 0,833526198 & \\
P(T<=t) one-tail & 0,209271236 & \\
t Critical one-tail & 1,761310115 & \\
P(T<=t) two-tail & 0,418542471 & \\
t Critical two-tail & 2,144786681 & \\
\end{tabular}

Berdasarkan keragaan yang ditunjukkan dalam bobot nodul akar tersebut, maka isolat bakteri nodul akar yang diperoleh dari akar putri malu layak untuk digunakan dalam uji aplikasi biofertilizer.

\subsubsection{Formulasi biofertilizer Trichoderma}

Isolat $\mathrm{T}$. harzianum yang digunakan sebagai agensia biofertilizer terformulasi dalam kompos yang sudah diinkubasi selama 2 minggu. Komposisi kimia kompos sebagai carrier bioferttilizer ini adalah: N..., P..., K..., C/N rasio...., dan $\mathrm{pH}$ 6,7. Setelah dilakukan penghitungan 
populasi dengan metode pengenceran, dketahui bahwa total populasi rata-rata Trichoderma dalam formula biofertilizer adalah $1,75 \times 10^{7} \mathrm{cfu} / \mathrm{g}$. Dosis biofettilizer per polibag kapasitas $5 \mathrm{~kg}$ adalah $100 \mathrm{gr}$, sehingga rata-rata populasi Trichoderma pada saat awal penanaman adalah $3,5 \times 10^{5}$ cfu/g tanah media tanam.

\subsubsection{Isolasi dan formulasi biofertilizer Mikoriza}

Hasil isolasi dari tanah agroforestri Coban Talun, Malang, yang akan digunakan sebagai lahan bagi pengembangan kedele diperoleh tiga macam endomikoriza dengan deskripsi seperti tertera pada Tabel 2 dan morfologi spora tertera pada Gambar 3.

Tabel 3. Deskripsi morfologi spora endomikoriza hasil penyaringan tanah Coban Talun.

\begin{tabular}{|l|l|l|c|}
\hline No. & Deskripsi mofologi spora & Jenis & $\begin{array}{l}\text { Populasi (spora/ } \\
100 \mathrm{~g} \text { tanah) }\end{array}$ \\
\hline 1 & $\begin{array}{l}\text { - Bentuk spora bulat lonjong } \\
\text { - Warna : coklat } \\
\text { - Spora berukuran } 149,15 \mu \mathrm{m} \\
\text { - Dinding sel berlapis } 2 \\
\text { dengan ketebalan 3,4 } \mu \mathrm{m}\end{array}$ & $\begin{array}{l}\text { Glomus } \\
\text { coronatum }\end{array}$ & 67 \\
\hline 2 & $\begin{array}{l}\text { - Bentuk spora bulat lonjong } \\
\text { - Warna : coklat tua } \\
\text { - Spora berukuran 141,22 } \mu \mathrm{m} \\
\text { - Dinding sebanyak 2 lapis } \\
\text { yang tebalnya 3,1 } \mu \mathrm{m}\end{array}$ & $\begin{array}{l}\text { Glomus } \\
\text { sp. 1 }\end{array}$ & \\
\hline 3 & $\begin{array}{l}\text { - Bentuk spora bulat lonjong } \\
- \text { Warna : coklat } \\
\text { - Spora berukuran } 132,12 \mu \mathrm{m} \\
\text { - Dinding sel berlapis 2 } \\
\text { dengan ketebalan 3,2 } \mu \mathrm{m}\end{array}$ & Glomus & \\
sp. 2 & \\
\hline
\end{tabular}



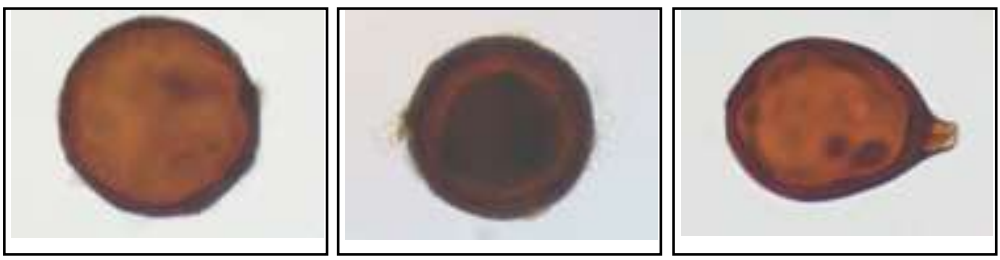

Gambar 3. Spora endomikoriza hasil isolasi yaitu Glomus coronatum, Glomus sp. 1, dan Glomus sp. 2.

Untuk selanjutnya jenis yang digunakan adalah Glomus coronatum untuk uji aplikasi biofertilizer. Setelah dilakukan perbanyakan pada tanaman jagung lokal, diperoleh populasi rata-rata 68 spora per gram tanah. Selanjutnya digunakan sebagai biofertilizer endomikoriza yang diaplikasikan [pada tanaman kedele dalam percobaan ini.

\subsection{Uji Aplikasi Biofertilizer}

\subsubsection{Pertumbuhan vegetatif}

Hasil analisis ragam menunjukkan naungan $60 \%$ berpengaruh nayata terhadap diameter batang pada 5 MST (F hitung 55,13 > F tabel 10,13). Sementara itu aplikasi biofertilizer berpengaruh nyata terhadap diameter batang 3 dan 5 MST (masing-masing $\mathrm{F}$ hitung 10,69 dan 11,89 > F tabel 5,99). Rerata pengaruh naungan $60 \%$ dan aplikasi biofertilizer mikoriza terhadap diameter batang dapat dilihat pada Tabel 2. 
Tabel 2. Rerata pengaruh naungan $60 \%$ dan aplikasi biofertilizer mikoriza terhadap diameter batang kedele 3 dan 5 minggu setelah tanam (MST) $(\mathrm{cm})$

\begin{tabular}{lcc}
\hline & \multicolumn{2}{c}{ Rerata diameter batang $\left.(\mathrm{cm})^{*}\right)$} \\
\cline { 2 - 3 } Perlakuan & 3 MST & 5 MST \\
\hline Petak utama: & & \\
Tanpa naungan (N0) & 0,16 & $0,42 \mathrm{a}$ \\
Naungan 60\% (N1) & 0,17 & $0,38 \mathrm{~b}$ \\
\hline BNT 5\% & - & 0,03 \\
\hline Anak petak: & & \\
Tanpa Mikoriza (M0) & $0,15 \mathrm{a}$ & $0,38 \mathrm{a}$ \\
Dengan Mikoriza (M1 & $0,18 \mathrm{~b}$ & $0,42 \mathrm{~b}$ \\
\hline BNT 5\% & 0,03 & 0,03 \\
\hline
\end{tabular}

*) Angka yang diikuti oleh huruf yang sama pada kolom yang sama masing-masing pada petak utama dan anak petak menunjukkkan tidak berbeda nyata berdasarkan uji BNT 5\%.

Hasil analisis ragam menunjukkan naungan $60 \%$ berpengaruh nayata terhadap panjang tanaman kedele pada 3 dan 5 MST (masing-masing F hitung 53,89> F tabel 10,13). Sementara itu aplikasi biofertilizer berpengaruh nyata terhadap panjang tanaman 3 dan 5 MST (masing-masing F hitung 24,15 dan 19,02 > F tabel 5,99). Rerata pengaruh naungan $60 \%$ dan aplikasi biofertilizer mikoriza terhadap panjang tanaman kedele dapat dilihat pada Tabel 3. 
Tabel 3. Rerata pengaruh naungan $60 \%$ dan aplikasi biofertilizer mikoriza terhadap panjang tanaman kedele 3 dan 5 minggu setelah tanam (MST) $(\mathrm{cm})$

\begin{tabular}{|c|c|c|}
\hline \multirow[b]{2}{*}{ Perlakuan } & \multicolumn{2}{|c|}{ Panjang tanaman $\left.(\mathrm{cm})^{*}\right)$} \\
\hline & $3 \mathrm{MST}$ & $5 \mathrm{MST}$ \\
\hline Petak utama: & & \\
\hline Tanpa naungan (N0) & 14,10 & 30,76 a \\
\hline Naungan 60\% (N1) & 15,46 & $56,29 \mathrm{~b}$ \\
\hline BNT 5\% & - & 5,74 \\
\hline
\end{tabular}

Anak petak:

Tanpa Mikoriza (M0) $\quad 13,58$ a $\quad 40,33$ a

Dengan Mikoriza (M1 $\quad 15,98$ b $\quad 46,73$ b

\begin{tabular}{lll}
\hline BNT 5\% & 0,62 & 5,74 \\
\hline
\end{tabular}

*) Angka yang diikuti oleh huruf yang sama pada kolom yang sama masing-masing pada petak utama dan anak petak menunjukkkan tidak berbeda nyata berdasarkan uji BNT 5\%.

Hasil analisis ragam menunjukkan naungan 60\% berpengaruh nayata terhadap jumlah daun tanaman kedele pada 5 MST (F hitung 45,84 > F tabel 10,13). Sementara itu aplikasi biofertilizer berpengaruh nyata terhadap jumlah daun tanaman pada 3 dan 5 MST (masing-masing F hitung 19,36 dan 29,92 > F tabel 5,99). Rerata pengaruh naungan $60 \%$ dan aplikasi biofertilizer mikoriza terhadap jumlah daun tanaman kedele dapat dilihat pada Tabel 4 . 
Tabel 4. Rerata pengaruh naungan $60 \%$ dan aplikasi biofertilizer mikoriza terhadap jumlah daun tanaman kedele 3 dan 5 minggu setelah tanam (MST) $(\mathrm{cm})$

\begin{tabular}{|c|c|c|}
\hline \multirow[b]{2}{*}{ Perlakuan } & \multicolumn{2}{|c|}{ Jumlah daun*) } \\
\hline & $3 \mathrm{MST}$ & $5 \mathrm{MST}$ \\
\hline Petak utama: & & \\
\hline Tanpa naungan (N0) & 11,56 & 18,91 a \\
\hline Naungan 60\% (N1) & 12,44 & $27,78 \mathrm{~b}$ \\
\hline BNT 5\% & & 3,49 \\
\hline
\end{tabular}

Anak petak:

Tanpa Mikoriza (M0) $\quad 11,38$ a $\quad 20,58$ a

Dengan Mikoriza (M1 $\quad 12,63$ b $\quad 26,10$ b

\begin{tabular}{lll}
\hline BNT 5\% & 0,62 & 3,49 \\
\hline
\end{tabular}

*) Angka yang diikuti oleh huruf yang sama pada kolom yang sama masing-masing pada petak utama dan anak petak menunjukkkan tidak berbeda nyata berdasarkan uji BNT 5\%.

\subsubsection{Nodul akar dan intensitas infeksi mikoriza}

Hasil analisis ragam menunjuk kan bahwa naungan $60 \%$ berpengaruh nyata terhadap bobot total nodul akar per tanaman (F hitung 122,64 > F tabel 10,13), namun tidak berpengaruh nyata terhadap intensitas infeksi mikoriza. Di lain pihak aplikasi biofertilizer mikoriza tidak berpengaruhnyata terhadap bobot total nodul akar pertanaman, tapi berpengaruh nyata terhadap intensitas infeksi mikoriza pada akar kedele (F hitung 149,14 > F tabel 5,99). Rerata bobot total nodul akar dan intensitas infeksi mikoriza disajikan pada Tabel 5. 
Tabel 5. Rerata pengaruh naungan $60 \%$ dan aplikasi biofertilizer mikoriza terhadap bobot total nodul akar dan intesitas infeksi mikoriza per tanaman kedele saat panen (11 MST)

\begin{tabular}{|c|c|c|}
\hline Perlakuan & $\begin{array}{c}\text { Bobot total } \\
\text { nodul akar (gr) }\end{array}$ & $\begin{array}{c}\text { Intensitas infeksi } \\
\text { mikoriza }(\%)\end{array}$ \\
\hline Petak utama: & & \\
\hline Tanpa naungan (N0) & $4,04 \mathrm{a}$ & 16,88 \\
\hline Naungan 60\% (N1) & $2,67 \mathrm{~b}$ & 18,50 \\
\hline BNT 5\% & 0,56 & - \\
\hline Anak petak: & & \\
\hline Tanpa Mikoriza (M0) & 3,33 & 0,00 \\
\hline Dengan Mikoriza (M1) & 3,69 & 35,38 \\
\hline BNT 5\% & - & 11,74 \\
\hline
\end{tabular}

*) Angka yang diikuti oleh huruf yang sama pada kolom yang sama masing-masing pada petak utama dan anak petak menunjukkkan tidak berbeda nyata berdasarkan uji BNT 5\%.

Intensitas infeksi mikoriza pada akar tanaman kedele diperlihatkan pada perlakuan tanpa naungan-bermikoriza serta (N0M1) dengan naungan-bermikoriza (N1M1) seperti tertera pada Gambar 2. Pada perlakuan tanpa naungan dan tanpa mikoriza (NOM0) tampak bahwa permukaan akar mulus tidak ada tonjolan, sedangkan pada perlakuan bermikoriza tampak tonjolan-tonjolan yang merupakan kumpulan hifa yang memasuki sel-sel dan ruang antar-sel akar. 

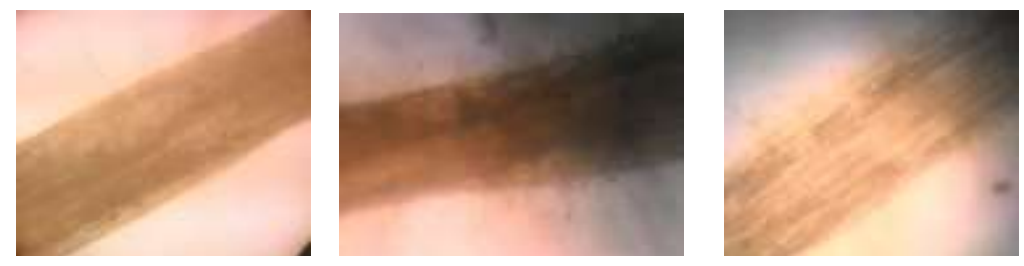

Gambar 2. Kondisi akar kedele tanpa infeksi mikoriza (N0M0) dan bermikoriza (N0M1 dan NiM1)

\subsubsection{Produksi tanaman}

Naungan 60\% dan aplikasi biofertilizer mikoriza masingmasing tidak berpengaruh nyata terhadap jumlah polong, bobot totoal panen, dan bobot 100 biji per tanaman kedele. Interaksi antara naungan 60\% dan aplikasi mikoriza juga tidak berpengaruh nyata terhadap seluruh variabel pengamatan produksi tanaman.

Jumlah polong, bobot total biji, dan bobot 100 biji ratarata per tanaman diperlihatkan pada Tabel 6. 
Tabel 6. Rerata pengaruh naungan $60 \%$ dan aplikasi biofertilizer mikoriza terhadap jumlah polong, bobot total biji, dan bobot 100 biji per tanaman kedele.

\begin{tabular}{lccc}
\hline Perlakuan & $\begin{array}{c}\text { Jumlah } \\
\text { polong }\end{array}$ & $\begin{array}{c}\text { Bobot } \\
\text { total biji } \\
\text { (gr) }\end{array}$ & $\begin{array}{c}\text { Bobot } \\
100 \mathrm{biji} \\
(\mathrm{gr})\end{array}$ \\
\hline $\begin{array}{l}\text { Petak utama: } \\
\text { Tanpa naungan (N0) }\end{array}$ & 88,63 & 11,08 & 10,94 \\
Naungan 60\% (N1) & 73,25 & 9,16 & 11,21 \\
Anak petak: & & & \\
Tanpa Mikoriza (M0) & 75,00 & 10,31 & 10,78 \\
Dengan Mikoriza (M1) & 86,88 & 10,68 & 11,37 \\
\hline
\end{tabular}

\subsection{Pembahasan Umum}

Isolat bakteri nodul akar yang berasal dari tumbuhan putri malu ( $M$. pudica) memiliki keragaan yang sama pada akar tanaman kedele dibandingkan dengan isolat bakteri nodul akar yang diperoleh dari akar kedele yang sama. Isolat ini diangap mewakili simbion efektif nodul akar tanaman kedele ketika dibudiayakan pada lahan kering yang sebelumnya relatif tidak dijumpai atau dibudidayakan tanaman kedele. Pada lahan kering kosong selalu dijumpai tumbuhan liar $M$. pudica yang memiliki kekerabatan dengan kedele.

Jika dilihat pada Tabel 2 dan 3 khususnya pada pengaruh naungan tampak bahwa tanaman yang ditumbuhkan di bawah naungan $60 \%$ memiliki rerata diameter $0,38 \mathrm{~cm}$ 
lebih kecil dibandingkan tanaman tanaman naungan yaitu 0,42 $\mathrm{cm}$ pada 5 MST. Di lain pihak tanaman di bawah naungan memiliki panjang tanaman jauh lebih tinggi dibandingkan tanaman tanpa naungan yaitu $56,29 \mathrm{~cm}$ dibandingkan 30,76 cm pada 5 MST. Sementara itu jumlah daun tanaman di bawah naungan rata-rata 27,78 helai jauh lebih tinggi dibandingkan dengan jumlah daun tanpa naungan yaitu 18,91 pada 5 MST (Tabel 4). Sejalan dengan hasil penelitian ini, Polthane, Promsaena, dan Laoken (2011) menunjukkan bahwa tinggi tanaman kedele di bawah naungan 50 dan $70 \%$ lebih tinggi dibandingkan tanpa naungan. Pada polong-polongan jenis lain yaitu kacang merah, tanaman yang diberi naungan 50\% memiliki rata-rata tinggi tanaman lebih besar dibandingkan kontrol (Komariah $d k k ., 2017)$.

Naungan juga berpengaruh terhadap jumlah daun (Tabel 5). Menurut Naidu dan Swamu (1993) intensitas cahaya yang rendah akan meningkatkan luas daun. Pada penelitian ini rata-rata jumlah daun pada 5 MST lebih tinggi pada perlakuan dengan naungan dibandingkan tanpa naungan.

Naungan menentukan intensitas cahaya matahari menerpa tajuk kedele dan suhu rata-rata di bawah naungan yang sudah tentu akan mempengaruhi laju pergerakan air melalui evapotranspirasi yang difasilitasi di antaranya 
melalui stomata (Penka, 1992). Dengan asumsi kadar air tanah normal (bukan dalam kondisi cekaman kekeringan), maka ada adaptasi selular di antaranya dalam pemanjangan sel dan komponen yang bertanggung-jawab terhadap transportasi air dan nutrisi termasuk dimensi stomata (Kumekawa et al., 2013; Sikarwar et al., 2014) yang direpresentasikan oleh pemanjangan tanaman dan total luas daun dan jumlah daun yang lebih tinggi. Di lain pihak kombinasi tingkat cahaya rendah dan konsentrasi $\mathrm{CO} 2$ tinggi dapat meningkatkan pemanfaatan cahaya fotosintetik (Wurth et al., 1998; DeLucia dan Thomas, 2000) dan meningkatkan efisiensi penggunaan cahaya dalam fotosintesis (Tomimatsu dan Tang, 2012). Fotosintesis dapat ditingkatkan oleh peningkatan konsenrasi $\mathrm{CO}_{2}$ pada spesies toleran naungan (Naumburg dan Ellsworth, 2000) termasuk kedele varietas lokal yang digunakan dalam penelitian ini. Meskipun tidak dilakan pengukuran konsentrasi $\mathrm{CO}_{2} \mathrm{di}$ sekitar tajuk, tapi kondisi di sekitar tanaman akan menyerupai kondisi pada umumnya di daerah tropis pada lantai hutan dengan konsentrasi $\mathrm{CO} 2$ yang selalu tinggi (Tang et al., 2003). Konsentrasi $\mathrm{CO}_{2}$ yang tinggi dapat meningkatkan pengambilan karbon melalui peningkatan efisiensi fotosintesis di bawah kondisi cahaya yang dinamis (Holisova et al., 2012; Tomimatsu dan Tang, 2012). Bahkan 
dengan konsentrasi $\mathrm{CO} 2$ yang tinggi berpotensi meningkatkan laju fotosintesis relatif pada kondisi light flecks (di bawah paranet intensitas rendah-menengah) dibandingkan pada kondisi staedy state (kontrol) (Leakey et al., 2005).

Secara keseluruhan naungan tidak berpengaruh terhadap variabel produksi tanaman yaitu jumlah polong, bobot 100 butir (Tabel 6). Ini agak berbeda dengan pernyataan Hayder (2003) dan Kakiuchi dan Kubota (2004) bahwa naungan berpengaruh pada penurunan produksi bahan kering dan jumlah polong total per tanaman, dan bobot total. Menurut Panhwar et al. (2004) naungan berdampak pada pertumbuhan tanaman kedele yang melemah. Namun demikian hasil penenlitian ini menunjukkan bahwa rata-rata masing-masing variabel produksi tersebut sedikit lebih tinggi pada perlakuan tanpa naungan.

Naungan tidak berpengaruh terhadap perbedaan perilaku fungi mikoriza dalam aktivitas infeksi akar, namun berpengaruh terhadap rata-rata bobot total nodul akar (Tabel $5)$.

Aplikasi biofertilizer mikoriza berpengaru nyata terhadap peningkatan pertumbuhan vegetatif tanaman. Hal ini ditunjukkan oleh rata-rata diameter batang (Tabel 2), panjang tanaman (Tabel 3), dan jumlah daun yang lebih 
tinggi (Tabel 4) pada perlakuan yang diberi biofertilizer mikoriza dibandingkan tanpa mikoriza. Adanya perbedaan pengaruh naungan $60 \%$ dan mikoriza terhadap variabel pertumbuhan vegetatif ternyata tidak sejalan bobot nodul akar dan produksi tanaman. Hal ini menunjukkan bahwa ukuran sel yang lebih tinggi dimensinya pada perlakuan pemberian naungan dibandingkan tanpa naungan tapi menunjukkan bobot yang tidak berbeda. Pada banyak hasil riset menunjukkan bahwa fungi endomikoriza membantu menyediakan nutrisi sehingga mampu meningkatkan pertumbuhan tanaman dan produksi tanaman (Rillig et al., 2001; Gianinazzi et al., 2010; Richardson et al., 2011; Legaya et al., 2016).

Intensitas infeksi mikoriza pada tanaman yang diberi biofertilizer endomikoriza rata-rata sebesar $35,38 \%$ relatif lebih kecil dibandingkan dengan intensitas infeksi fungi mikoriza tanaman kedele lokal lainnya pada berbagai hasil penelitian terdahulu di antaranya yaitu mencapai 33,51-42,73 (Muis, Indradewa, dan Widada, 2013), 44,44-70,20\% (Sitanggang, Rahmawati, dan Hanum, 2014), dan 43,33\% (Putra, Syafruddin, dan Jumini, 2016). Hal ini diduga bahwa tanaman sudah mendapat dukungan nutrisi dari fungi Trichoderma yang diberikan dalam bentuk biofertilizer Trichoderma yang terformulasi dalam bentuk kompos. Terdapat persinggungan habitus di antara kedua jenis fungi 
ini yang memungkinkan adanya persaingan dalam memanfaatkan rhizosfer. Hifa eksternal fungi mikoriza dalam kondisi normal dapat mencapai jarak yang jauh melampaui capaian penyebaran akar (Read dan PerezMoreno, 2003; Smith dan Smith, 2011). Oleh karenanya dalam kondisi demikian fungi mikoriza berperan membantu tanaman dalam menyuplai air dan nutrisi dari sumbernya yang tidak dapat dicapai akar tanaman.

Dugaan adanya persaingan ruang itu bisa dibuktikan dengan minimnya hifa eksternal fungi mikoriza yang menyembul dari dalam akar tanaman seperti ditunjukkan pada Gambar 2. Tampak bahwa sembulan hifa dari dalam ekar relatif sangat sedikit, sehingga tidak tampak perbedaan yang nyata dengan akar tanaman kedele tanpa mikoriza. Karakteristik Trichoderma yang menghasilkan enzim kitinase (Vinale et al., 2008) yang dapat mendegradasi kitin yang merupakan molekul kerangka sel fungi. T. viridae dan T. pseudokoningii mendegradasi sklerotia Sclerotium cepivorm (Clarkson et al., 2004). Hilangnya struktur hifa eksternal di luar sel-sel akar juga diduga meruapkan mekanisme internal fungi dalam meningkatkan efisiensi respirasi, mengingat respirasi hifa di luar akar lebh tinggi dari pada di dalam sel bahkan lebih tinggi dari laju respirasi akar 
halus (Nottingham et al., 2010; Neumann dan Matzner, 2014).

Kecilnya intensitas infeksi mikoriza, selain adanya persaingan ruang, di duga tanaman tidak mengandalkan suplai nutrisi dari hifa fungi mikoriza maupun maupun disediakan oleh fungi mikoirza melalui mekanisme dekomposisi (Talbot et al., 2008). T. harzianum membantu tanaman dalam halam menyediakan nutrisi hasil dekomposisi bahan organik (Cheng, Johnson, dan Fu, 2003; Howel, 2003; Dayana Amira et al., 2012; Buysens et al., 2016;), menghasilkan senyawa elkstraselular yang berperan sebagai zat pengatur tumbuh bagi tanaman (Gravel et al., 2007; Chowdappa et al., 2013; Yousef et al., 2016), di samping memberi kenyamanan tanaman karena bersifat sebagai mikoparasit melindungi dari patogen (Harman, 2006; Verma et al., 2007) serta dapat meningkakan ketahanan tanaman terhadap cekaman patogen dan cekaman lingkungan (Harman et al., 2004; Vargas, Pastorb, dan Marcha, 2009; Srivastava et al., 2010).

Secara keseluruhan eksistensi bakteri nodul akar, Trichoderma, dan endomikoriza telah meningkatkan kualitas rhizosfer. Cheng et al., (2003) menunjukkan efek rhizosfer priming atau kondisi awal rhizosfer tanaman kedele, di mana peningkatan laju dekomposisi bahan organik tanah 383\% 
lebih tinggi dibandingkan kontrol (tanpa tanaman); sementara itu pemupukan NPK tidak secara signifikan mengubah efek priming rizosfer atau laju dekompisisi bahan organik. Memperkuat pendapat itu, Talbot et al. (2008) menduga bahwa endomikoriza menghasilkan enzim litik ekstraseluler yang berperan menghasilkan efek priming rhisofer yaitu fungi mikoriza menguraikan $\mathrm{C}$ tanah ketika alokasi fotosintat tanaman ke akar bermikoriza tinggi, sehingga pertumbuhan tanaman dan aktivitas fungi mikoriza menjadi prima. 


\section{BAB VI \\ KESIMPULAN DAN SARAN}

\subsection{Kesimpulan}

Isolat bakteri nodul akar dari tumbuhan putri malu (Mimosa pudica) memiliki keragaan yang sama dengan isolat bakteri nodul akar yang berasal dari tanaman kedele dan layak digunakan sebagai biofertilizer untuk penanaman baru pada lahan kering kedele.

Naungan $60 \%$ berpengaruh terhadap pertembuhan vegetatif tanaman, jumlah nodul akar, namun tidak berpengaruh terhadap intensitas infeksi mikoriza, jumlah polong, bobot total biji, dan bobot 100 biji kedele varietas Dena-1.

Biofertilizer endomikoriza Glomus berpengaruh terhadap pertumbuan vegetatif dan intensitas infeksi mikoriza namun tidak berpengaruh terhadap bobot totoal bintil akar, jumlah polong, bobot total biji, dan bobot 100 biji tanaman kedele.

Tidak terdapat pengaruhn interaksi antara naungan $60 \%$ dengan aplikasi biofertilizer endomikoriza terhadap pertumbuhan dan produksi kedele varietas Dena-1. 


\subsection{Saran}

Mengingat luasnya lahan kering di Indonesia, maka pengembangan penanaman kedele varietas tahan naungan perlu dilakukan pada berbagai sistem agroforestri, sistem huma dan perladangan, dan hutan rakyat yang berpotensi dioptimalkan pemanfaatannya.

Perlu diujicobakan pemanfaatan biofertilizer Trichoderma dan mikoriza yang terformulasi dalam bahan ogrnaik dalam penanaman kedele tahan naungan di dalam berbagai sistem agroforestri, sistem huma dan perladangan, dan hutan rakyat ketika musim kemarau untuk mengetahui kemampuan agensia biofertilzer dalam mengendalikan dan meningkatkan efisiensi penggunaan air oleh tanaman kedele. 


\section{DAFTAR PUSTAKA}

AlAskar AA \& Rashad YM. 2010. Arbuscular mycorrhizal fungi: a biocontrol agent against common bean Fusarium root rot disease. Plant Pathol. J. 9, 31-38.

Alguacil MM, Torrecillas E, García-Orenes F \& Roldán A. 2014. Changes in the composition and diversity of AMF communities mediated by management practices in a Mediterranean soil are related with increases in soil biological activity. Soil Biol. Biochem. 76, 34-44.

Al-Taweil HI, Osman MB, Aidil AH \& Wan-Yussof WM. 2009. Optimizing of Trichoderma viride cultivation in submerged state fermentation. Am. J. Appl. Sci. 6, $1277-1281$.

Altieri, M.A. and C.I. Nicholis. 2005. Agroecology and the Search for a Truly Sustainable Agriculture. Mexico. United Nations Environments Programme.

Anonim. 2017. Jokowi: Pemanfaatan 36,8 Juta Hektare Lahan Pertanian Belum Maksimal. http://katadata.co.id/berita/2016/12/07/jokowi-pemanfaat an-368-juta-hektare-lahan-pertanian-belum-maksimal.

Diakses. Diakses 22 April 2017.

Atman. 2006. Pengelolaan Tanaman Kedelai di Lahan Kering Masam. Jurnal Tambua, 5 (3): 281-287.

Badan Pusat Statistik (BPS), 2016. "Luas Panen Kedelai Menurut Provinsi (ha), 1993-2015", https://www.bps.go.id/ linkTableDinamis/view/id/870. Diakses 1 May 2017.

Balitbang Pertanian. 2016. Varietas Dena 1. Badan penelitian dan pengembangan pertanian. Kementrian pertanian. http://new.litbang.pertanian.go.id/varietas/1092/. diakses 09 april 2017. 
Benítez T, Rincón AM, Limón MC \& Codon A. 2004. Biocontrol mechanisms of Trichoderma strains. Int. Microbiol. 7 (4), 249-260.

Buysens C, César V, Ferrais F, De Boulois HD \& Declerck S. 2016. Inoculation of Medicago sativa cover crop with Rhizophagus irregularis and Trichoderma harzianum increases the yield of subsequently-grown potato under low nutrient conditions. Applied Soil Ecology 105,137-143.

Camenzind T, Homeier J, Dietrich K, Hempel S, Hertel D, Krohn A, Leuschner C, Oelmann Y, Olsson PA, Suarez JP \& Rillig MC. 2016. Opposing effects of nitrogen versus phosphorus additions on mycorrhizal fungal abundance along an elevational gradient in tropical montane forests. Soil Biology \& Biochemistry 94, 37-47.

Cavallazzi JRP, Filho OK, Stürmer SL, Rygiewicz PT \& de Mendonça MM. 2007. Screening and selecting arbuscular mycorrhizal fungi for inoculating micropropagated apple rootstocks in acid soils. Plant Cell Tissue Organ Cult. 90, 117-129. doi:http://dx.doi.org/10.1007/s11240-006-9163-6.

Cheng W, Johnson DW \& Fu S. 2003. Rhizosphere effects on decomposition. Soil Sci. Soc. Am. J. 67, 1418-1427. doi:http://dx.doi.org/10.2136/sssaj2003.1418.

Chowdappa P, Kumar SPM, Lakshmi MJ \& Upreti KK. 2013. Growth stimulation and induction of systemic resistance in tomato against early and late blight by Bacillus subtilis OTPB1 or Trichoderma harzianum OTPB3. Biol. Control 65, 109-117.

Clarkson JP, Mead A, Payne T \& Whipps JM. 2004. Effect of environmental factors and Sclerotium cepivorum isolate on sclerotial degradation and biological control 
of white rot by Trichoderma. Plant Pathol. 53, 353362.

Dakora, F.D., S.B.M. Chimpango; A.J. Valentine, C. Elmerich, and W.E. Newton. 2008. Biological Nitrogen Fixation: Towards Poverty Alleviation through Sustainable Agriculture. Netherland.

Dayana Amira R, Roshanida AR, Rosli MI, Zahrah SFMF, Anuar MJ \& Adha NCM. 2012. Bioconversion of empty fruit bunch (EFB) and palm oil mill effluent (POME) into compost using Trichoderma virens. African Journal of Biotechnology 10, 18775-18780.

DeLucia EH \& Thomas RB, "Photosynthetic responses to $\mathrm{CO}_{2}$ enrichment of four hardwood species in a forest understorey". Oecologia, vol. 122, pp. 11-19, 2000.

Dubey SC, Suresha M \& Singha B. 2007. Evaluation of Trichoderma species against Fusarium oxysporum f. sp. ciceris for integrated management of chickpea wilt. Biol. Control 40, 118-127.

Foyer, C.H. and G. Noctor. 2004. Photosynthetic Nitrogen Assimilation and Associated Carbon and Respiratory Metabolism. London. Kluwer Academic Publisher.

Gams W \& Bissett J. 2002. Morphology and identification of Trichoderma. In: Kubicek CP \& Harman GE (Eds.). Trichoderma and Gliocladium, Volume 1: Basic biology, taxonomy and genetics. pp. 3-34. Taylor \& Francis Ltd. London.

García-González I, Quemada M, Gabriel JL \& Hontoria C. 2016. Arbuscular mycorrhizal fungal activity responses to winter cover crops in a sunflower and maize cropping system. Applied Soil Ecology 102, 1018. 
Geisseler D \& Horwath WR. 2009. Relationship between carbon and nitrogen availability and extracellular enzyme activities in soil. Pedobiologia 53, 87-98.

Gianinazzi S, Gollotte A, Binet MN, van Tuinen D, Redecker D \& Wipf D. 2010. Agroecology: the key role of arbuscular mycorrhizas in ecosystem services. Mycorrhiza 20, 519-530.

Glare T, Caradus J, Gelernter W, Jackson T, Keyhani N, Kohl J, Marrone P, Morin L \& Stewart A. 2012. Have biopesticides come of age? Trends Biotechnol. 30, 250258.

Gravel V, Antoun H \& Tweddell RJ. 2007. Growth stimulation and fruit yield improvement of greenhouse tomato plants by inoculation with Pseudomonas putida or Trichoderma atroviride: possible role of indole acetic acid (IAA). Soil Biol. Biochem. 39, 1968-1977.

Harman GE, Howell CR, Viterbo A, Chet I \& Lorito M. 2004. Trichoderma species - opportunistic, avirulent plant symbionts. Nat. Rev. Microbiol. 2, 43-56.

Harman GE. 2006. Overview of mechanisms and uses of Trichoderma spp. Phytopathology 96, 190-194.

Hayder G, Mumraz SS, Khan A, \& Khan S. 2003. Maize and soybean intercropping under various levels of soybean seed rates. Asian Journal of Plant Sciences 2, 339-341. doi:10.3923/ajps.2003.339.341.

Heinemeyer A, Hartley IP, Evans SP, Carreira De La Fuente JA \& Ineson P. 2007. Forest soil CO2 flux: uncovering the contribution and environmental responses of ectomycorrhizas. Glob. Change Biol. 13, 1786-1797. doi:http://dx.doi.org/10.1111/j.13652486.2007.01383.x.

Holisova P, Zitova M, . Klem K, \& Urban O. 2012. Effect of elevated carbondioxide concentration on carbon 
assimilation under fluctuating light. J Environ Qual. 41, 1931-1938.

Howell CR. 2003. Mechanisms employed by Trichoderma species in the biological control of plant diseases: the history and evolution of current concepts. Plant Dis. 87, 4-10.

Hu X, Roberts DP, Xie L, Yu C, Li Y, Qin L, Hu L, Zhang Y \& Liao X. 2016. Use of formulated Trichoderma sp. Tri-1 in combination with reducedrates of chemical pesticide for control of Sclerotinia sclerotiorium on oilseed rape. Crop Protection 79, 124-127.

Kakiuchi J \& Kobata T. 2004. Shading and thinning effects on seed and shoot dry matter increase in determinate soybean during the seed-filling period. Agronomy Journal, 96, 398-405 doi:10.2134/agronj2004.0398

Komariah A, Waloeyo EC, \& Hidayat O. 2017. Pengaruh penggunaan naungan terhadap pertumbuhan dan hasil dua varietas tanaman kacang merah (Phaseolus vulgaris L.). Paspalum 5 (1): 33-41.

Kumekawa Y, Miyata H, Ohga K, Hayakawa H, Yokoyama J, Ito $\mathrm{K}$, Tebayashi $\mathrm{S}$, Arakawa $\mathrm{R}$, \& Fukuda T. 2013. Comparative analyses of stomatal size and density among ecotypes of Aster hispidus (Asteraceae). American Journal of Plant Sciences 4, 524-527.

Kuzyakov Y \& Larionova AA. 2005. Root and rhizomicrobial respiration: a review of approaches to estimate respiration by autotrophic and heterotrophic organisms in soil. J. Plant Nutr. Soil Sci. 168, 503-520. doi:http://dx.doi.org/10.1002/jpln.200421703.

Leakey ADB, Scholes JD, \& Press MC. 2005. Physiological and ecological significance of sunflecks for dipterocarp seedlings". J Exp Bot. 56, 469-482. 
Legaya N, Grassein F, Binet MN, Arnoldi C, Personeni E, Perigon S, Polyd F, Pommier T, Puissant J, Clément JC, Lavorel S \& Mouhamadou B. 2016. Plant species identities and fertilization influence on arbuscular mycorrhizal fungal colonisation and soil bacterial activities. Applied Soil Ecology 98, 132-139.

Lichtfouse, E. 2010. Sustainable Agriculture Reviews 3. Sociology, Organic Farming, Climate Change, and Soil Science. Netherlands. Springer.

Ma HX, Feng XJ, Chen Y, Chen CJ \& Zhou M. 2009. Occurrence and characterization of dimethachlon insensitivity in Sclerotinia sclerotiorum in Jinagsu Province of China. Plant Dis. 93, 36-42.

Martinson GO, Corre MD \& Veldkamp E. 2013. Responses of nitrous oxide fluxes and soil nitrogen cycling to nutrient additions in montane forests along an elevation gradient in southern Ecuador. Biogeochemistry 112, 625-636.

Moyano F, Kutsch W \& Schulze E. 2007. Response of mycorrhizal, rhizosphere and soil basal respiration to temperature and photosynthesis in a barley field. Soil Biol. Biochem. 39, 843-853. doi:http://dx.doi.org/10.1016/j.soilbio.2006.10.001.

Muis A, Indradewa D , Widada J. 2013. Pengaruh inokulasi mikoriza arbuskula terhadap pertumbuhan dan hasil kedelai (Glycine max (1.) Merrill) pada berbagai interval penyiraman. Vegetalika 2 (2): 7-20.

Naidu CV \& Swamu PM. 1993. Effect of shade on growth, biomass production and associated physiological parameters in Pongamia Pinnata (Linn.) Pierre. Indian Journal of Plant Physiology 37, 212-214.

Naumburg E \&. Ellsworth DS, 2000, Photosynthesis sunfleck utilization potential of understory saplings growung 
under elevated $\mathrm{CO}_{2}$ in FACE. Oecologia. 122, 163174.

Neumann J \& Matzner E. 2014. Contribution of newly grown extramatricalectomycorrhizal mycelium and fine roots to soil respiration in a young Norway spruce site. Plant Soil 378, 73-82. doi:http://dx.doi.org/10.1007/s11104013-2018-0.

Noortasiah, 2005. Pemanfaatan Bakteri Rhizobium pada tanaman kedelai di lahan lebak. Buletin Teknik Pertanian, 10 (2): 57-60.

Nottingham AT, Turner BL, Winter K, van der Heijden MGA \& Tanner EVJ. 2010. Arbuscular mycorrhizal mycelial respiration in a moist tropical forest. New Phytol. 186, 957-967. doi:http://dx.doi.org/10.1111/j.14698137.2010.03226.x.

Nurudin MJ dan Sutarman. 2014. Potensi Trichoderma sp sebagai pengendali Phytopthora palmivora penyebab hawar daun bibit kakao. J Nabatia 11 (1): 21-28.

Panhwar MA, Mempn FH, Kalhoro MA, \& Somro MI. 2004. Performance of maize in intercropping system with soybean under different planting patterns and nitrogen levels. Journal of Applied Science 4, 201-204. doi:10.3923/jas.2004.201.204.

Paul EA \& Clarck FE. 1996. Soil microbiology and biochemistry 2nd ed. Academic Press. San Diego.

Penka M. 2012. Stomatal and cuticular transpiration. In: Sebanek J (ed.). Plant physiology,. pp.55-64. Elsivier, Amsterdam.

Polthanee A, Promsaena K, \& Laoken A. 2011. Influence of low light intensity on growth and yield of four soybean cultivars during wet and dry seasons of Northeast 
Thailand. Agricultural Sciences 2 (2): 61-67. doi:10.4236/as.2011.22010.

Polthanee A \& Treloges V. 2002. Growth and yield of mungbean cultivars in mungbean-corn relay intercropping systems. Journal of International Society for Southeast Asian Agricultural Sciences 8, 1-14.

Pruksakorna $\mathrm{P}$, Araia M, Kotokua N, Vilchèze C,. Baughn AD, Moodley P, Jacobs WR Jr. \& Kobayashia M. 2010. Trichoderins, novel aminolipopeptides from a marine sponge-derived Trichoderma sp., are active against dormant mycobacteria. Bioorganic \& Medicinal Chemistry Letters 20 (12): 3658-3663

Purwaningsih, S. 2005. Rhizobium dari tanah kebun biologi Wamena. Biodiversitas. 6(2): 82-84.

Putra RR, Syafruddin, \& Jumini. 2016. Produksi dan mutu benih beberapa varietas kedelai lokal aceh (Glycine $\max$ (1.) Merr.) dengan pemberian dosis mikoriza yang berbeda pada tanah entisol. Jurnal Kawista 1 (1) : 3744.

Read D \& Perez-Moreno J. 2003. Mycorrhizas and nutrient cycling in ecosystems - a journey towards relevance? New Phytologist 157, 475-492.

Richardson A, Lynch J, Ryan P, Delhaize E, Smith FA, Smith SE, Harvey P, Ryan M, Venklaas E, Lambers H, Oberson A, Culvenor R \& Simpson R. 2011. Plant and microbial strategies to improve the phosphorus efficiency of agriculture. Plant and Soil 349, 121-156.

Rillig MC, Wright SF, Nichols KA, Schmidt WF \& Torn MS. 2001. Large contribution of arbuscular mycorrhizal fungi to soil carbon pools in tropical forest soils. Plant Soil 233, 167-177.

Samuels GJ. 2006. Trichoderma: Systematics, the Sexual State, and Ecology. Phytopathology 96 (2): 195-206. 
Saravanakumar K, Yu C, Dou K, Wang M, Li Y \& Chen J. 2016. Synergistic effect of Trichoderma-derived antifungal metabolites and cell wall degrading enzymes on enhanced biocontrol of Fusarium oxysporum f. sp. cucumerinum. Biological Control 94 (2016) 37-46.

Sarjan M dan Sab'i. 2014. Karakteristik Polong Kedelai Varitas Unggul yang Terserang Hama Pengisap Polong (Riptortus linearis) pada Kondisi Cekaman Kekeringan. Jurnal Lahan Suboptimal 3 (2): 168-180

Shanmugaiah V, Balasubramanian N, Gomathinayagam S, Monoharan PT \& Rajendran A. 2009. Effect of single application of Trichoderma viride and Pseudomonas fluorences on growth promotion in cotton plants. Afr. J. Agric. Res. 4, 1220-1225.

Sikarwar R, Rajawat BS, \& Sharma KR. 2014. Studies on relationship between stomatal density and oleoresin yield in chirpine (Pinus roxburghii Sargent). International Journal of Advanced Research 2,751-758.

Singh, B., R. Kaur, and K. Singh. 2008. Characterization of Rhizobium Strain Isolated from the Roots of Trigonella foenumgraecum (fenugreek). African Journal of Biotechnology. 7 (20): 3671- 3676.

Sitanggang RM, Rahmawati N, \& Hanum C. 2014. Pertumbuhan kedelai melalui aplikasi asam askorbat dan inokulasi fungi mikoriza arbuskular pada lahan salin dengan tingkat salinitas yang berbeda. Jurnal Online Agroekoteknologi 2 (4): 1589 - 1595.

Six J, Elliott ET \& Paustian K. 2000. Soil macroaggregate turnover and microaggregate formation: a mechanism for $\mathrm{C}$ sequestration under no-tillage agriculture. Soil Biol. Biochem. 32, 2099-2103. 
Smith SE \& Smith FA. 2011. Roles of arbuscular mycorrhizas in plant nutrition and growth: new paradigms from cellular to ecosystem scales. Annual Review of Plant Biology 62, 227-250.

Srivastava R., Khalid A, Singh US \& Sharma AK. 2010. Evaluation of arbuscular mycorrhizal fungus, fluorescent Pseudomonas and Trichoderma harzianum formulation against Fusarium oxysporum f. sp. lycopersici for the management of tomato wilt. Biological Control 55, 24-31.

Sullivan, P. 2003. Applying the Principles of Sustainable Farming. Fundamental of Sustainable Agriculture. ATTRA.

Suriadikarta DA \& Simanungkalit RDM. 2006. Pendahuluan. In: Simanungkalit RDM, Suriadikarta DA, Saraswati R, Setyorini D \& Hartatik W (eds.). Pupuk organic dan pupuk hayati. Pp. 1-10. Balai Besar Litbang Sumberdaya Lahan Pertanian, Badan Penelitian dan Pengembangan Pertanian. Bogor.

Sutarman. 2016a. Seleksi Trichoderma Spp Dari Bawah Tegakan Pinus Dan Uji Daya Dukung Isolat Terpilih Terhadap Pertumbuhan Tomat Dan Sawi. Hlm. 125-134 dalam Prosiding Konser Karya Ilmiah Nasional; Salatiga, 4 Agustus 2016. Prihtanti TM dan Herawati MM (peny,), Salatiga, Indonesia, Universitas Kristen Satya Wacana, Salatiga.

Sutarman. 2016b Pengujian Trichoderma sebagai pengendali hawar daun bibit kakao yang disebabkan oleh Phytopthora palmivora. J Hama Penyakit Tropika 17 (1): 51-56.

Talbot JM, Allison SD \& Treseder KK. 2008. Decomposers in disguise: mycorrhizal fungi as regulators of soil $\mathrm{C}$ dynamics in ecosystems under global change. Funct. Ecol. 
doi:http://dx.doi.org/10.1111/j.13652435.2008.01402.x.

Tang Y, Okuda T, Awang M, Rahim Nik A, \& Tani M. 2003. Sunfleck contribution to leaf carbon gain in tree seedlings from gap and the understorey in a troical rain forest. Biotropica 31, 268-278.

Tomamitsu H \& Tang Y. 2012. Elevated $\mathrm{CO}_{2}$ differentially affects photosynthetic induction response in two Populus species with different stomatal behavior. Oecologia 169, 869-878.

Tomè E, Tagliavini M \& Scandellari F. 2015. Recently fixed carbon allocation in strawberry plants and concurrent inorganic nitrogen uptake through arbuscular mycorrhizal fungi. J. Plant Physiol. 179, 83-89. doi:http://dx.doi.org/10.1016/j.jplph.2015.02.008.

Van der Heijden MG, Streitwolf-Engel R, Riedl R, Siegrist S, Neudecker A, Ineichen K, Boller T, Wiemken A \& Sanders IR. 2006. The mycorrhizal contribution to plant productivity, plant nutrition and soil structure in experimental grassland. New Phytologist 172, 739-752.

Vargas Gil S, Pastorb S \& Marcha GJ. 2009. Quantitative isolation of biocontrol agents Trichoderma spp. Gliocladium spp. and Actinomycetes from soil with culture media. Microbiol. Res. 164, 196-205.

Verma M, Brar SK, Tyagi RD, Surampalli RY \& Valero JR. 2007. Antagonistic fungi, Trichoderma spp.: panoply of biological control. Biochemistry Engineering Journal 37, 1-20.

Vinale F, Sivasithamparam K, Ghisalberti EL, Marra R, Barbetti MJ, Li H, Woo SL \& Lorito M. 2008. A novel role for Trichoderma secondary metabolites in the interactions with plants. Physiol. Mol. Plant Pathol. 72, 80-86. 
Vinale F, Sivasithamparam K, Ghisalberti EL, Marra RS, Woo L \& Lorito M. 2008. Trichoderma-plantpathogen interactions. Soil Biol. Biochem. 40, 1-10.

Voets L, De Boulois HD, Renard L, Strullu DG \& Declerck

S. 2005. Development of an autotrophic culture system for the in vitro mycorrhization of potato plantlets. FEMS Microbiol. Lett. 248, 111-118.

Wang B \& Qiu YL. 2006. Phylogenetic distribution and evolution of mycorrhizas in land plants. Mycorrhiza 16, 299-363.

Werner, D. and W.E. Newton. 2005. Nitrogen Fixation in Agriculture, Forestry, Ecology and the Environment. Netherlands. Springer.

Wurth KR, Winter R, \& Korner C. 1998. In situ responses to elevated $\mathrm{CO} 2$, in tropical forest understorey plant". Func Ecol. 12, 886-895.

Yedidiaa I, Benhamoub N, Kapulnikc Y \& Cheta I. 2000. Induction and accumulation of PR proteins activityduring early stages of root colonizationby the mycoparasite Trichoderma harzianum strain T-203. Plant Physiology and Biochemistry 38 (11): 863-873.

Yulida M. 2016. Ini Jurus Kementan dan F AO Agar Lahan Kering Bisa Digarap Petani. https://finance.detik.com/ekonomi-bisnis/3364375/ini-jur us-kementan-dan-fao-agar-lahan-kering-bisa-digarap-pet an. Diakses 2 Mei 2017.

Youssef SA, Tartoura KA \& Abdelraouf GA. 2016. Evaluation of Trichoderma harzianum and Serratia

proteamaculans effect on disease suppression, stimulation of ROS-scavenging enzymes and improving tomato growth infected by Rhizoctonia solani. Biological Control 100, 79-86. 


\section{LAMPIRAN}

Lampiran 1. Deskrisi kedelai varietas dena-1 (Balitbang Pertanian, 2016)

Karakteritik Kedelai varietas dena-1:

Tipe tumbuh $\quad:$ determinit

Tinggi tanaman $: 59 \mathrm{~cm}$

Potensi hasil : $2,89 \mathrm{t} / \mathrm{ha}$

Rata-rata hasil $\quad: 1,69 \mathrm{t} / \mathrm{ha}$

Bentuk biji : lonjong

Ukuran biji : besar

Bobot 100 biji $\quad: 11,07-16,06 \mathrm{~g}$

Kandungan protein $: 36,67 \%$

Kandunga lemak $: 18.81 \%$

Umur : 78 hari

Tahan penyakit : karat

Tahun : 2014 
Lampiran 2. Analisis kimia tanah media tanam 
18BN 978-970-3401-60-s

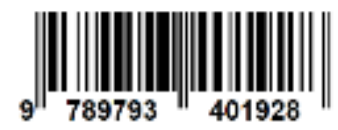

